\title{
Anatomical Characterization, Physical, and Chemical Properties of Wood of Quercus macdougallii Martínez, Endemic Species of the Sierra Juárez of Oaxaca, Mexico
}

Faustino Ruiz-Aquino, ${ }^{\text {a }}$ Lizbeth Luna-Bautista, ${ }^{\text {a }}$ Aremi E. Luna-Bautista, ${ }^{a}$ Wenceslao Santiago-García, ${ }^{a}$ Luis F. Pintor-Ibarra, ${ }^{b}$ and José G. Rutiaga-Quiñones ${ }^{\text {b, } *}$

The anatomical characteristics and the physical and chemical properties of wood of Quercus macdougallii Martínez are presented for the first time. Q. macdougallii Martínez is an endemic species of the Sierra Juarez of Oaxaca. The microscopic characteristics were described in preparations of typical cuts and dissociated material. The physical properties were evaluated according to the ASTM D 143-94 standard in sapwood and heartwood specimens. The measurable elements and physical properties were classified according to the mean. With the measurable elements, the paper pulp quality index was determined. In sapwood and heartwood, the basic chemical composition was determined. The wood of $Q$. macdougallii presented a pronounced grain, a thick texture, and a straight thread. Fibers, fibrotracheids, uniseriate, multiseriate, and aggregate rays were found. Basic density $0.55 \mathrm{~g} \mathrm{~cm}^{-3}$ in sapwood and $0.61 \mathrm{~g} \mathrm{~cm}^{-3}$ in heartwood is classified as moderately heavy and heavy, respectively. The saturation point of the fiber is classified as high. Based on its physical properties, $Q$. macdougallii wood can be used in the manufacture of furniture, veneer, floors, tool handles, and construction. Based on the pulp quality indices and chemical composition, this wood could be used to obtain cellulose pulp for paper.

Keywords: Sapwood; Wood basic density; Pulp quality indexes; Wood chemistry

Contact information: a: Instituto de Estudios Ambientales, Universidad de la Sierra Juárez, Avenida Universidad S/N, , Ixtlán de Juárez, Oaxaca, C.P. 68725 México; b: Facultad de Ingeniería en Tecnología de la Madera, Edificio "D", Ciudad Universitaria, Universidad Michoacana de San Nicolás de Hidalgo, Av. Fco. J. Múgica S/N, Col. Felicitas del Rio, Morelia, Michoacán, C. P. 58040, México;

*Corresponding author: rutiaga@umich.mx

\section{INTRODUCTION}

Oaks belong to the genus Quercus in the family Fagaceae, which comprises 8 to 10 genera and more than 900 species (Kremer et al. 2012). The genus Quercus is distributed throughout Mexico with 161 registered species. The states with the highest number of species are Oaxaca (48), Nuevo León (47), Jalisco (45), Chihuahua (40), and Veracruz (38) (Valencia and Nixon 2004).

The Sierra Norte in the state of Oaxaca has the highest species diversity with 23 of the total registered. Quercus macdougallii Martínez, the endemic species of the Sierra de Juárez in Oaxaca, is distributed in this region due to its reduced geographical and altitudinal distribution (Valencia and Nixon 2004).

Quercus macdougallii is a monoecious evergreen tree that can grow up to $40 \mathrm{~m}$ high, and the stem diameter can reach $4 \mathrm{~m}$ as an adult. Additionally, its flowering period is from May to July and it bears fruit from November to January (Clark-Tapia et al. 2018). It 
is distributed within the mountainous system called Sierra Madre de Oaxaca, specifically in the municipalities of San Pedro Yólox and Santiago Comaltepec. The area includes a mountain range with different elevations from 2648 to $3274 \mathrm{~m}$ above sea level (AnacletoCarmona 2015).

Studies related to $Q$. macdougallii have been limited to tree structure and diversity (Anacleto-Carmona 2015), acorns sexual reproduction (Clark-Tapia et al. 2018), the effect of magnetite nanoparticles on the germination, early growth of Q. macdougallii (Pariona et al. 2017), and the delimitation of the climatic intervals where the maximum abundance of the species occurs (Antúnez et al. 2018).

The distribution of $Q$. macdougallii is restricted, with low abundance. Clark-Tapia et al. (2018) found sites with 150 trees per hectare, while Antúnez et al. (2018), report the presence of the species in 33 sites of $1000 \mathrm{~m}^{2}$. However, information related to the characteristics of its wood was lacking. Therefore, the aim of this study was to perform the macroscopic and microscopic anatomical description of the wood. Additionally, the study evaluated the physical properties at different heights of the stem, and the chemical composition, as a contribution to the technological knowledge of the wood in this species.

\section{EXPERIMENTAL}

\section{Materials}

Study area

The study area was in the forests of the community of Santiago Comaltepec in the Sierra Norte of Oaxaca, at coordinates $17^{\circ} 33^{\prime} 50^{\prime \prime} \mathrm{LN}$ and $96^{\circ} 32^{\prime} 52^{\prime \prime} \mathrm{LO}$ with altitude levels ranging from 450 to $3,000 \mathrm{~m}$ (INEGI 2016). The climate in this zone is temperate with low temperatures from November to February (minimum average $4.7^{\circ} \mathrm{C}$ ) and high temperatures from March to May (maximum average 13.4 ${ }^{\circ} \mathrm{C}$ ) (Robson 2008; Antúnez et al. 2018). The average rainfall is $767 \mathrm{~mm}$ (Clark-Tapia et al. 2016). The collection site is located at coordinates $07^{\circ} 64^{\prime} 129^{\prime \prime} \mathrm{LN}$ and $19^{\circ} 45^{\prime} 810^{\prime \prime} \mathrm{LO}$ at an altitude of $2936 \mathrm{~m}$.

\section{Tree selection}

A $Q$. macdougallii tree was studied that was knocked down by the wind. The tree showed straightness of stem and was free of pests or diseases. The tree had a diameter of $28 \mathrm{~cm}$ at breast height and a total height of $13 \mathrm{~m}$. Dimensioning was done according to the methodology of Ramos and Diaz (1981). Logs of $40 \mathrm{~cm}$ in length were cut at different heights above ground level $(0.30 \mathrm{~m}, 1.30 \mathrm{~m}, 3 \mathrm{~m}$, and $6 \mathrm{~m})$. A botanical sample was collected and identified in the herbarium of the University of Sierra Juarez. Based on the availability of the study material, it was only possible to describe the wood with one individual (De la Paz Pérez and Quintanar 1994; Bárcenas et al. 2005; De la Paz Pérez and Dávalos-Sotelo 2008). However, the values obtained for some physical properties should be considered with some caution.

\section{Methods}

Macroscopic and microscopic anatomical characterization

For the macroscopic description, a $30-\mathrm{cm}$ thick slice obtained at $1.30 \mathrm{~m}$ above ground level was used. From the slice, sapwood and heartwood tablets were obtained and oriented in the three planes: radial, tangential, and transversal (De la Paz-Pérez and Dávalos-Sotelo 2008). The color was described using Munsell tables (1975). Texture, 
thread, grain, luster, and smell were classified according to Tortorelli (1956). The color, gloss, and smell were organoleptically tested.

For microscopic characterization, 4 slices of samples at $5 \mathrm{~cm}$ thickness obtained at different heights $(0.30 \mathrm{~m}, 1.30 \mathrm{~m}, 3 \mathrm{~m}$, and $6 \mathrm{~m})$ were used. 2 by $2 \mathrm{~cm}$ cubes oriented in the transverse, tangential, and radial planes were cut (De la Paz-Pérez and Quintanar 1994), and the samples were labeled with the corresponding height data.

To make the histological cuts, the cubes were softened by boiling with distilled water for $8 \mathrm{~h}$ (De la Paz Pérez et al. 2015). The cuts were made with a Leica SMR2010 microtome (Leica, Buffalo Grove, IL, USA), and $15 \mu \mathrm{m}$ thick lamellae were obtained in the following planes: transversal, tangential, and radial for sapwood and heartwood (De la Paz Pérez et al. 2006). Samples were stained by mixing distilled water, $96 \%$ alcohol, and safranin (García et al. 2003) dehydrated in a series of alcohols. The samples were finally rinsed in xylol for 2 min (Ruiz-Aquino et al. 2016). 50 permanent preparations were made by height for sapwood and heartwood (Navarro-Martínez et al. 2005).

For the preparation of the dissociation, small chips were cut from the material used for the histological cuts (Pineda et al. 2012). The small chips were placed in glass flasks. Glacial acetic acid and hydrogen peroxide at $30 \%$ were added (1 to $1 \mathrm{v}$ per v) and were placed in the oven at $60{ }^{\circ} \mathrm{C} \pm 5^{\circ} \mathrm{C}$ for $24 \mathrm{~h}$ (Interián-Ku et al. 2011).

\section{Measurements}

The measurements were made on digital images from the Motic BA310LED optical microscope with an integrated camera and transferred to the Motic Images Plus ML Version 2.0 software (Motic, British Columbia, CA). The measurable elements (vessel elements, fibers, and rays) were classified based on the average according to Chattaway (1932) and the IAWA Committee (1937, 1939, 1989). 50 measurements were made per type of constituent element at each height and per type of wood. The length of the multiserial rays was only measured 25 times (Valencia and Barajas 1995; Aguilar and Castro 2006; Chávez et al. 2010).

The vessel elements were classified in wide diameter (greater than $150 \mu \mathrm{m}$ ) and narrow diameter (less than or equal to $150 \mu \mathrm{m}$ ) (Chávez et al. 2010). The diameter and number of vessels per $\mathrm{mm}^{2}$ were measured on the cross-section of the histological sections and the length of the vessel elements in the dissociated material.

The length, overall diameter, lumen diameter, and cell wall thickness in the dissociated material were measured for the wood fibers. The number, cell number, and length of the uniseriate rays in the tangential section of the histological sections were recorded. The length of the multiseriate rays was measured with a Mitutoyo vernier (Mitutoyo, Aurora IL, USA) on the cross section of the wooden slats. The width and series number of the multiseriate rays were measured on the histological slices.

\section{Pulp quality indexes for paper}

Pulp quality indexes were calculated based on the following relationships given by Dadswell et al. (1959) and cited by Villaseñor-Araiza and Rutiaga-Quiñones (2000): stiffness coefficient (2 times the cell wall thickness per fiber diameter), flexibility coefficient (lumen diameter per fiber diameter), slenderness index (fiber length per fiber diameter), and Runkel index (2 times the cell wall thickness per lumen diameter). The classification of the pulp quality indexes for paper was based on the Runkel classification presented previously (Petroff and Nordman 1965; Porres and Valladares 1979) and cited by Villaseñor-Araiza and Rutiaga-Quiñones (2000). Group I (up to 0.25) was classified as 
excellent, Group II (from 0.25 to 0.50 ) was very good, Group III (from 0.50 to 1.00 ) was good, Group IV (from 1.00 to 2.00) was regular, and Group V (above 2.00) was unsatisfactory.

\section{Physical properties}

From each of the logs, $5 \mathrm{~cm}$ thick slices were cut at different heights $(0.30 \mathrm{~m}, 1.30$ $\mathrm{m}, 3 \mathrm{~m}$, and $6 \mathrm{~m}$ ). In each slice, sapwood and heartwood specimens were obtained according to the ASTM D 143-94 standard (2007). The physical properties determined were basic density, normal density (12\% M. C.), green density, anhydrous density, volumetric, radial, tangential, and longitudinal shrinkage. The fiber saturation point (FSP) was calculated from Fuentes-Salinas (2000) equation as shown in Eq. 1,

$$
F S P=V S \times(0.9 \times \text { basic density })^{-1}
$$

where FSP represents the fiber saturation point, and VS represents volumetric shrinkage.

The anisotropy ratio $(R A)$ was calculated according to Eq. 2,

$$
R A=S t \times(S r)^{-1}
$$

where $R A$ represents the anisotropy ratio, St represents tangential shrinkage, and $\mathrm{Sr}$ represents radial shrinkage.

\section{Chemical analysis}

To determine the basic chemical composition of the wood of $Q$. macdougallii, wood samples were taken at different heights above ground level as mentioned earlier. From each slice, sapwood and heartwood were separated. This material was milled and sieved using the 40-mesh fraction. The chemical analysis included the determination of $\mathrm{pH}$ (Sandermann and Rothkamm 1959), the content of inorganic substances using the technique T 211 om-93 (TAPPI 2000), the solubility against organic solvents, the amount of lignin (Runkel and Wilke 1951), and the amount of holocellulose (Wise et al. 1946). For solvent solubility, a successive extraction in Soxhlet equipment was applied using cyclohexane, acetone, methanol, and finally hot water under reflux (Mejía-Díaz and Rutiaga-Quiñones 2008). In each case, the extraction lasted 6 h. Chemical analyses were performed in triplicate.

The inorganic elements in the ash were identified and quantified using an X-ray spectrometer connected to a Jeol JSM - 6400 scanning electron microscope (JEOL, Dearborn, MI, USA). The operating conditions were the same as reported by TéllezSánchez et al. (2010), $20 \mathrm{kV}$ and $8.5 \mathrm{~s}$.

\section{Statistical analysis}

A completely randomized experimental design was performed in which the four heights per type of wood (sapwood-heartwood) were compared. The parameters to be evaluated were the measurable anatomical elements (vessels, fibers, uniseriate, and multiseriate rays), pulp quality indexes, and physical properties (moisture content, basic density, anhydrous density, green density, normal density, volumetric shrinkage, fiber saturation point, linear shrinkage, and anisotropy ratio). For the anatomical elements, 50 repetitions per height were performed, and for the physical parameters, 18 repetitions per height. When significant differences in the parameters were found, a comparison of means was made using Tukey's HSD test $(\alpha=0.05)$. Statistical analysis was performed with the SAS $®$ statistical package Version 9.0 (SAS Institute Inc., Cary, NC, USA). 


\section{RESULTS AND DISCUSSION}

\section{Macroscopic Anatomical}

The wood of $Q$. macdougallii presented a very pale brown color $(10 \mathrm{YR} 8 / 2)$ in contrast to the heartwood, which is reddish yellow (5YR6/6). It has no characteristic smell, and the taste is bitter, a distinctive feature of the Quercus genus. This coincides with what has been reported for Q. magnoliifolia, Q. obtusata, and Q. crassifolia (Honorato 2002). The color, smell, and taste of the wood is given by the presence of extracts such as tannins and polyphenols that are deposited in the lumens and cell walls (De la Paz Perez 2000).

The brightness of the wood was medium (Fig. 1), a characteristic that occurs when the wood has annular porosity. The wood grain was pronounced, a feature that is determined by the vessels and the axial or longitudinal parenchyma. The wide multiseriate rays that make the grain more attractive also contribute to pronounced wood grain (Moglia et al. 2014).

The wood of $Q$. macdougallii presented a thick texture, a characteristic of the oaks Quercus castanea Née and Quercus acutifolia Née (De la Paz Pérez and Dávalos-Sotelo 2008). The thread of $Q$. macdougallii is straight and the woods with this characteristic present less shrinkage in contrast to woods that present inclined, spiral, or interlocked thread (León and Espinoza 2001). In addition, it facilitates the manufacture of turned and carved products.
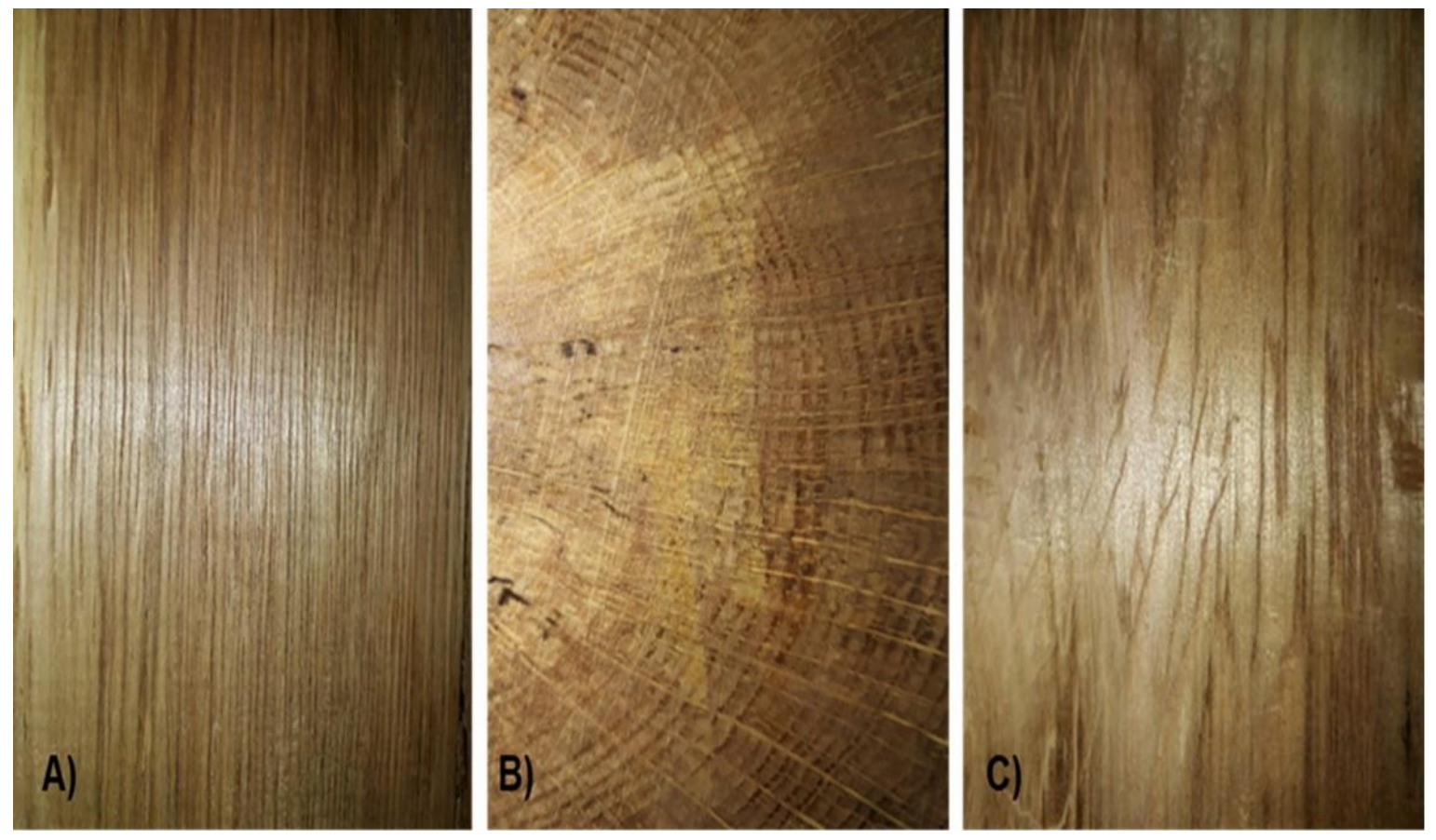

Fig. 1. Macroscopic characteristics of $Q$. macdougallii wood: A) tangential section, B) cross section, C) radial section

\section{Microscopic Anatomical Characteristics}

Vessels

The wood of $Q$. macdougallii presented annular porosity, which is associated with medium or high densities, and are the most recommended in the manufacture of hand tools handles (hammers, axes, picks, shovels, among others). This is where the wood is subjected 
to impact stress. The force received perpendicular to the thread is dispersed mainly in the lumens of the larger vessels (Rodríguez et al. 2007).
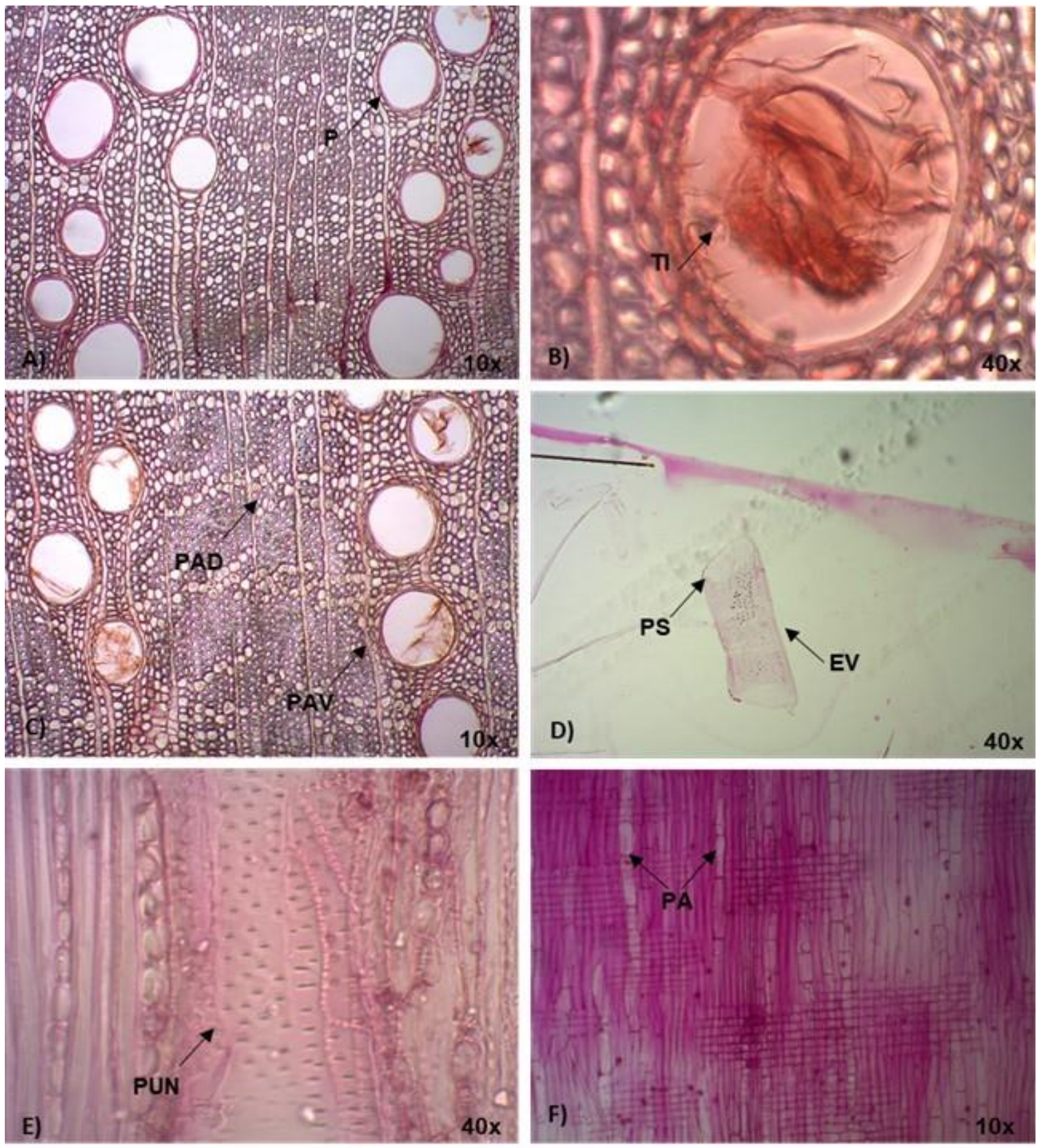

Fig. 2. Elements of vessels of $Q$. macdougallii: A) annular porosity: P: pore (10x); B) TI: pore with presence of tyloses (40x); C) cross section: PAD: diffuse apotracheal parenchyma, PAV: vasicentric paratracheal parenchyma (10x); D) EV: vessel element, PS: simple perforation plate (40x); E) tangential section: PUN: bordered pits with oval contour (40x); F) radial section: PA: parenchyma (10x)

The pores are solitary, have an oval contour, are arranged in radial rows, some present tyloses, and the axial parenchyma is apotracheal diffuse and paratracheal vasicentric. These results correspond with what has been reported for Quercus glaucoides Mart and Gal (Honorato 2002) and Q. obtusata (Chávez et al. 2010). The vessel elements presented simple perforation plates and alternate areolated pits of an oval shape (Fig. 2). 
In the cross section, the vessels have medium pores (IAWA 1939). The pores per $\mathrm{mm}^{2}$ in sapwood are few and moderately few in heartwood (Chattaway 1932). With respect to length, they are classified as medium for both sapwood and heartwood (Chattaway 1932). These are characteristics like those reported by Ruiz-Aquino et al. (2016) for $Q$. laurina, and $Q$. crassifolia.

The diameter and number of pores favor the penetration of liquids, while the vessels without obstructions favor the preservation process (Honorato 2002). However, the presence of tyloses makes the entrance of fungal hyphae and the circulation of water and oxygen difficult. Tyloses serves as a physical barrier for the entrance of pathogens and make the wood impenetrable (Moglia et al. 2014).

In the statistical analysis of sapwood by height, significant differences were found in the number of vessels per $\mathrm{mm}^{2}(\mathrm{p}=0.0001)$, where heights 1 and 2 are different at height 4 (Table 1). The number of pores per $\mathrm{mm}^{2}$ increased from the base to the crown, which was the case for Quercus garryana Dougl. (Lei et al. 1996). The structure of the wood varies by species, within each species, between trees, and even in the specimens. They can vary from the pith towards the exterior or from the base of the trunk to the crown (Zobel and Talbert 1994; Quintanar et al. 2012).

Table 1. Elements of the Wooden Vessels of $Q$. macdougallii by Height

\begin{tabular}{|c|c|c|c|c|c|c|}
\hline \multirow{2}{*}{ Dimensions } & \multirow{2}{*}{ Type } & \multicolumn{4}{|c|}{ Height (m) } & \multirow{2}{*}{ Mean } \\
\hline & & 0.30 & 1.30 & 3.00 & 6.00 & \\
\hline \multirow{2}{*}{$\mathrm{D}>150 \mu \mathrm{m}$} & Sapwood & $\begin{array}{c}189.94 \\
(40.02) \mathrm{a} \\
\mathrm{A}\end{array}$ & $\begin{array}{c}191.94 \\
(28.10) a, A\end{array}$ & $\begin{array}{c}191.04 \\
(25.48), \mathrm{a} \\
\text { A }\end{array}$ & $\begin{array}{c}185.47 \\
(24.67), \mathrm{a} \mathrm{A}\end{array}$ & $\begin{array}{c}189.59 \\
(30.70) A\end{array}$ \\
\hline & Heartwood & $\begin{array}{c}182.64 \\
(22.49) \mathrm{b} \\
\mathrm{A}\end{array}$ & $\begin{array}{c}177.18 \\
(26.44) a b \\
B \\
\end{array}$ & $\begin{array}{c}167.68 \\
(13.67) a, B\end{array}$ & $\begin{array}{c}171.26 \\
(26.54) \mathrm{a}, \mathrm{B}\end{array}$ & $\begin{array}{c}174.69 \\
(20.79) \mathrm{B}\end{array}$ \\
\hline \multirow{2}{*}{$\mathrm{D} \leq 150 \mu \mathrm{m}$} & Sapwood & $\begin{array}{c}119.99 \\
(21.43) a \\
A\end{array}$ & $\begin{array}{c}114.42 \\
(23.24) \mathrm{a}, \mathrm{B}\end{array}$ & $\begin{array}{c}114.22 \\
(22.12) a, A\end{array}$ & $\begin{array}{c}119.40 \\
(21.08) a, A\end{array}$ & $\begin{array}{c}117.01 \\
(21.98) A\end{array}$ \\
\hline & Heartwood & $\begin{array}{c}115.75 \\
(27.42) \mathrm{b} \\
\mathrm{A}\end{array}$ & $\begin{array}{c}99.67 \\
(27.87) \mathrm{a}, \mathrm{A}\end{array}$ & $\begin{array}{c}120.05 \\
(19.04) b, B\end{array}$ & $\begin{array}{c}116.31 \\
(22.64) \mathrm{b}, \mathrm{A}\end{array}$ & $\begin{array}{c}112.94 \\
(25.57) \mathrm{A}\end{array}$ \\
\hline \multirow{2}{*}{$\begin{array}{l}\text { Length } \\
(\mu \mathrm{m})\end{array}$} & Sapwood & $\begin{array}{c}505.8 \\
(99.32) a \\
B\end{array}$ & $\begin{array}{c}522.28 \\
(124.53) \mathrm{a} \\
\mathrm{B}\end{array}$ & $\begin{array}{c}485.24 \\
(101.76) a \\
B\end{array}$ & $\begin{array}{c}481.51 \\
(97.17) \mathrm{a}, \mathrm{B}\end{array}$ & $\begin{array}{c}496.96 \\
(106.11) \mathrm{B}\end{array}$ \\
\hline & Heartwood & $\begin{array}{c}476.82 \\
(123.65) a \\
A\end{array}$ & $\begin{array}{c}505.27 \\
(114.76) a \\
A\end{array}$ & $\begin{array}{c}443.92 \\
(84.65) \mathrm{a}, \mathrm{A}\end{array}$ & $\begin{array}{c}468.86 \\
(97.32) \mathrm{a}, \mathrm{A}\end{array}$ & $\begin{array}{c}476.27 \\
(106.66) \mathrm{A}\end{array}$ \\
\hline \multirow{2}{*}{$\begin{array}{c}\text { Number } \\
\left(\mathrm{mm}^{-2}\right)\end{array}$} & Sapwood & $\begin{array}{c}5(1.38) a, \\
A\end{array}$ & $\begin{array}{c}5(1.71) \mathrm{a} \\
\mathrm{A}\end{array}$ & $\begin{array}{c}6(2.02) \\
a b, A\end{array}$ & $\begin{array}{c}7(2.36) b \\
A\end{array}$ & $6(2.01) \mathrm{A}$ \\
\hline & Heartwood & $\begin{array}{c}5(1.69) \mathrm{a}, \\
\mathrm{A}\end{array}$ & $9 \begin{array}{c}(5.34) b \\
B\end{array}$ & $9 \begin{array}{c}(2.35) \\
B\end{array}$ & $\begin{array}{c}10(3.85) \\
b, B\end{array}$ & $8(4.07) \mathrm{B}$ \\
\hline \multicolumn{7}{|c|}{$\begin{array}{l}\text { *Note: } D \text { is the vessel diameter, equal lowercase letters in the direction of the rows indicate } \\
\text { statistical equality }(p<0.05) \text {, and equal uppercase letters in the direction of the columns } \\
\text { indicate statistical equality by type of wood }(p<0.05) \text {. The values in parenthesis represent the } \\
\text { standard deviation. }\end{array}$} \\
\hline
\end{tabular}

Vessels with diameters greater than $150 \mu \mathrm{m}$ were significantly larger in sapwood with respect to heartwood $(\mathrm{p}=0.0001)$. This can be attributed to sapwood being made up of cells whose function is to conduct water and nutrients (Wilson and White 1986). The 
diameters and lengths of the vessels of the species studied increase from the pith to the bark, which was also reported by Phelps and Workman (1994), Sousa et al. (2014), and Leal et al. (2011) for the wood of Quercus alba, Q. faginea, and $Q$. suber, respectively.

The size of the vessels is related to density. Woods that have a higher frequency of vessels and larger vessels will have lower density than those with small vessels (Panshin and Dezeeuw 1980). Additionally, the longer the vessels, the more likely the wood will present cracks (Savilla 1986).

\section{Fibers}

In sapwood and heartwood, libriform fibers and fibrotracheids were identified (Fig. 3). Based on the mean, the fiber diameter was classified as fine (Tortorelli 1956), the fiber wall thickness as medium (IAWA 1939), and the length as medium (IAWA 1937). These were similar characteristics to those reported for Quercus hintonii and $Q$. affinis by De la Paz Pérez et al. (2006). With Quercus castanefolia, they coincide in lumen diameter (Kiaei and Samariha 2011). Also, similarity in fiber diameter was found in the wood of Quercus polymorpha (González et al. 2016) and similar values in fiber length were found in those reported for Q. obtusata (Chávez et al. 2010) and Q. sideroxyla (De la Paz Pérez and Corral 1980).

The dimensions of the fibers intervene in the physical and mechanical behavior of the wood, where the total volume and the thickness of the cell wall directly influence the density. Species with thick walls have high density (González et al. 2016). The length, diameter, and thickness of the fiber wall influence the properties of the pulp and the paper that is made from it. The resistance to tearing of the paper is related to the length. Therefore, the greater the length the greater the resistance (Dinwoodie 1965). Pulps obtained from thin-walled fibers with large diameters are characterized by high tensile and breaking strength (Honorato 2002). The length of the fibers plays a predominant role when efforts are applied in a direction parallel to the grain (León and Espinoza 2001).

Statistically there were significant differences in the parameters analyzed between heights (Table 2). The total diameter of the fibers and the diameter of the lumen increase from the pith to the bark. This behavior also was exhibited in the wood of Quercus castaneifolia (Bakhshi et al. 2012) and Q. faginea (Sousa et al. 2014).
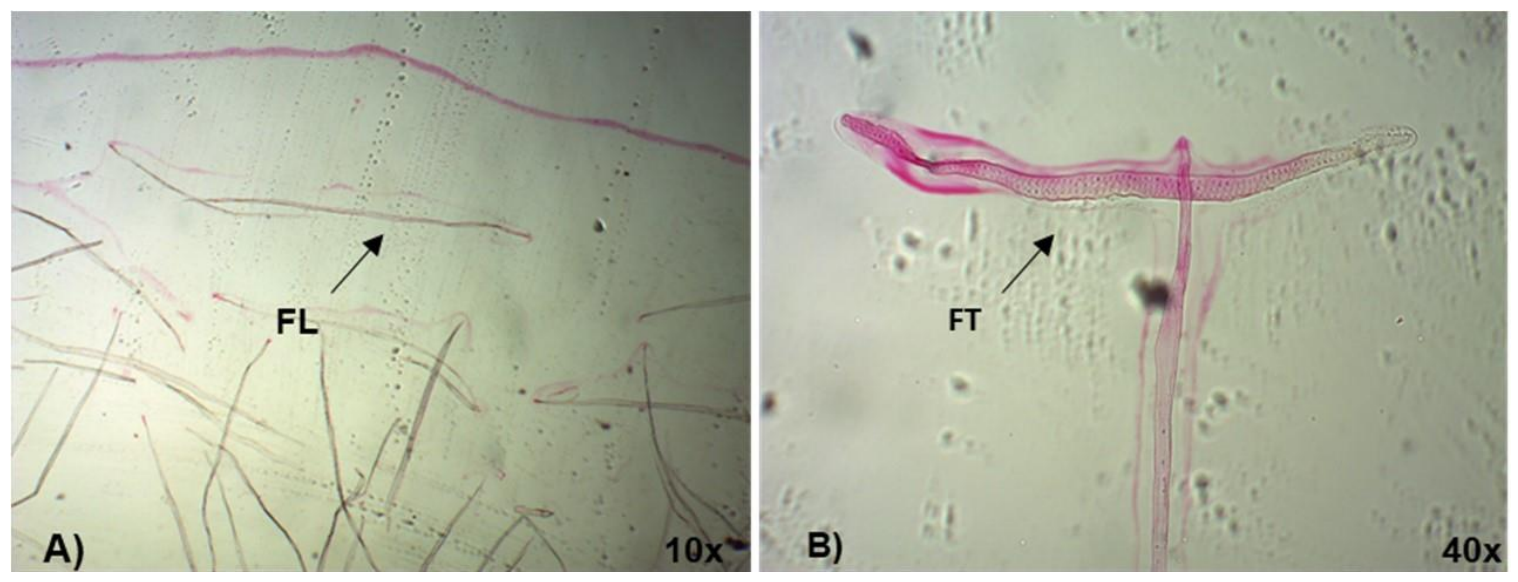

Fig. 3. Cellular elements of $Q$. macdougallii wood (fibers): A) FL: libriform fiber (10x); B) FT: fibrotracheids (40x) 
Table 2. Wood Fibers of $Q$. macdougallii by Height

\begin{tabular}{|c|c|c|c|c|c|c|}
\hline \multirow{2}{*}{ Dimensions } & \multirow{2}{*}{ Type } & \multicolumn{4}{|c|}{ Height (m) } & \multirow{2}{*}{ Mean } \\
\hline & & 0.30 & 1.30 & 3.00 & 6.00 & \\
\hline \multirow{2}{*}{$\begin{array}{l}\text { Diameter } \\
(\mu \mathrm{m})\end{array}$} & Sapwood & $\begin{array}{c}17.27 \\
(3.50) \mathrm{ab}, \mathrm{B}\end{array}$ & $\begin{array}{c}17.01 \\
(2.73) \mathrm{a}, \mathrm{B}\end{array}$ & $\begin{array}{c}18.03 \\
(3.35) \mathrm{b}, \mathrm{A}\end{array}$ & $\begin{array}{c}16.78 \\
(4.42) a, B\end{array}$ & $\begin{array}{c}17.27(0.54) \\
B\end{array}$ \\
\hline & Heartwood & $\begin{array}{c}15.16 \\
(2.93) \mathrm{a}, \mathrm{A}\end{array}$ & $\begin{array}{c}15.79 \\
(3.66) \mathrm{a}, \mathrm{A}\end{array}$ & $\begin{array}{c}19.19 \\
(5.23) \mathrm{b}, \mathrm{A}\end{array}$ & $\begin{array}{c}14.14 \\
(3.65) \mathrm{a}, \mathrm{A}\end{array}$ & $\begin{array}{c}16.07(2.19) \\
A\end{array}$ \\
\hline \multirow{2}{*}{$\mathrm{DL}(\mu \mathrm{m})$} & Sapwood & $\begin{array}{c}9.37 \\
(2.29) \mathrm{ab}, \mathrm{B}\end{array}$ & $\begin{array}{c}8.04 \\
(1.98) \mathrm{a}, \mathrm{B}\end{array}$ & $\begin{array}{c}10.80 \\
(3.31) \mathrm{b}, \mathrm{A}\end{array}$ & $\begin{array}{c}9.03(3.81) \\
a, \mathrm{~B}\end{array}$ & $\begin{array}{c}9.31(3.09) \\
\mathrm{B}\end{array}$ \\
\hline & Heartwood & $\begin{array}{c}3.79 \\
(1.07) \mathrm{a}, \mathrm{A}\end{array}$ & $\begin{array}{c}6.03 \\
(2.54) \mathrm{b}, \mathrm{A}\end{array}$ & $\begin{array}{c}10.55 \\
(4.37) \mathrm{c}, \mathrm{A}\end{array}$ & $\begin{array}{c}6.79(2.86) b \\
A\end{array}$ & $\begin{array}{c}6.79(3.81) \\
A\end{array}$ \\
\hline \multirow{2}{*}{$\mathrm{GP}(\mu \mathrm{m})$} & Sapwood & $\begin{array}{c}3.95 \\
(1.04) \mathrm{ab}, \mathrm{A}\end{array}$ & $\begin{array}{c}4.49 \\
(1.21) \mathrm{b}, \mathrm{A}\end{array}$ & $\begin{array}{c}3.57 \\
(0.78) \mathrm{a}, \mathrm{A}\end{array}$ & $\begin{array}{c}3.87(1.32) \mathrm{a} \\
\mathrm{A}\end{array}$ & $\begin{array}{c}3.97(1.15) \\
A\end{array}$ \\
\hline & Heartwood & $\begin{array}{c}5.69 \\
(1.33) \mathrm{c}, \mathrm{B}\end{array}$ & $\begin{array}{c}4.88 \\
(1.39) \mathrm{b}, \mathrm{A}\end{array}$ & $\begin{array}{c}4.32 \\
(1.08) \mathrm{ab}, \mathrm{A}\end{array}$ & $\begin{array}{c}3.68(1.19) \mathrm{a} \\
\mathrm{A}\end{array}$ & $\begin{array}{c}4.64(1.45) \\
A\end{array}$ \\
\hline \multirow{2}{*}{$\begin{array}{l}\text { Longitudinal } \\
(\mu \mathrm{m})\end{array}$} & Sapwood & $\begin{array}{c}1349.85 \\
(248.99) a \\
A\end{array}$ & $\begin{array}{c}1452.31 \\
(192.23) b \\
A\end{array}$ & $\begin{array}{c}1410.30 \\
(172.06) a b \\
A\end{array}$ & $\begin{array}{c}1492.58 \\
(178.88) b, A\end{array}$ & $\begin{array}{c}1427.56 \\
(205.56) A\end{array}$ \\
\hline & Heartwood & $\begin{array}{c}1403.31 \\
(233.30) a \\
\text { A }\end{array}$ & $\begin{array}{c}1638.21 \\
(201.29) a \\
A\end{array}$ & $\begin{array}{c}1349.99 \\
(190.77) a \\
A\end{array}$ & $\begin{array}{c}1495.14 \\
(120.57) a, A\end{array}$ & $\begin{array}{c}1471.66 \\
(199.03) \mathrm{A}\end{array}$ \\
\hline
\end{tabular}

\section{Uniseriate and multiseriate rays}

Uniseriate rays are classified. Because of their width being extremely thin, the number of uniseriate rays per $\mathrm{mm}^{2}$ are numerous (IAWA 1939), but according to the length are extremely low (Chattaway 1932). The rays of $Q$. macdougallii show 12 cells on average (Fig. 4). The above characteristics are similar to those reported for $Q$. affinis (Valencia and Barajas 1995) and are lower when compared to those reported for Q. magnoliifolia (De la Paz-Pérez and Dávalos-Sotelo 2008).

The dimensions of the rays are anatomic variables with greater influence in the drying process because they present a flexible primary cell wall (barely thickened). They constitute weak points in the wood due to the absence of the secondary wall (Metcalfe and Chalk 1985). The presence of abundant uniseriate rays can negatively affect the mechanical properties and the tangential contraction of the wood (Bárcenas et al. 2002).

Also, the wood of $Q$. macdougallii presented homogeneous, multiseriate, and aggregates woody rays. According to the width, they are classified as very wide (IAWA 1939) with an average of 14 series and by its length are classified as very high (Chattaway 1932) (Fig. 3). These characteristics are like those reported for Quercus durifolia von Seem (De la Paz-Perez and Davalos-Sotelo 2008) and Q. castanea (Palacios et al. 2013).

Multiseriate rays are the most distinctive characteristic of oak wood (De la Paz Pérez et al. 2015) due to the influence they have on the technological properties of wood. They intervene in the grain, texture, and shrinkage, causing cracks that decrease the quality of the wood during drying. The latter increases with the abundance of fibers and thick walls (Ávila 1985; De la Paz Pérez et al. 1998; De la Paz Pérez et al. 2005).

In both sapwood and heartwood, there was an increase in the length of the uniseriate rays as height increased (Table 3 ). The same behavior was observed with the number of uniseriate rays per $\mathrm{mm}^{2}$. 

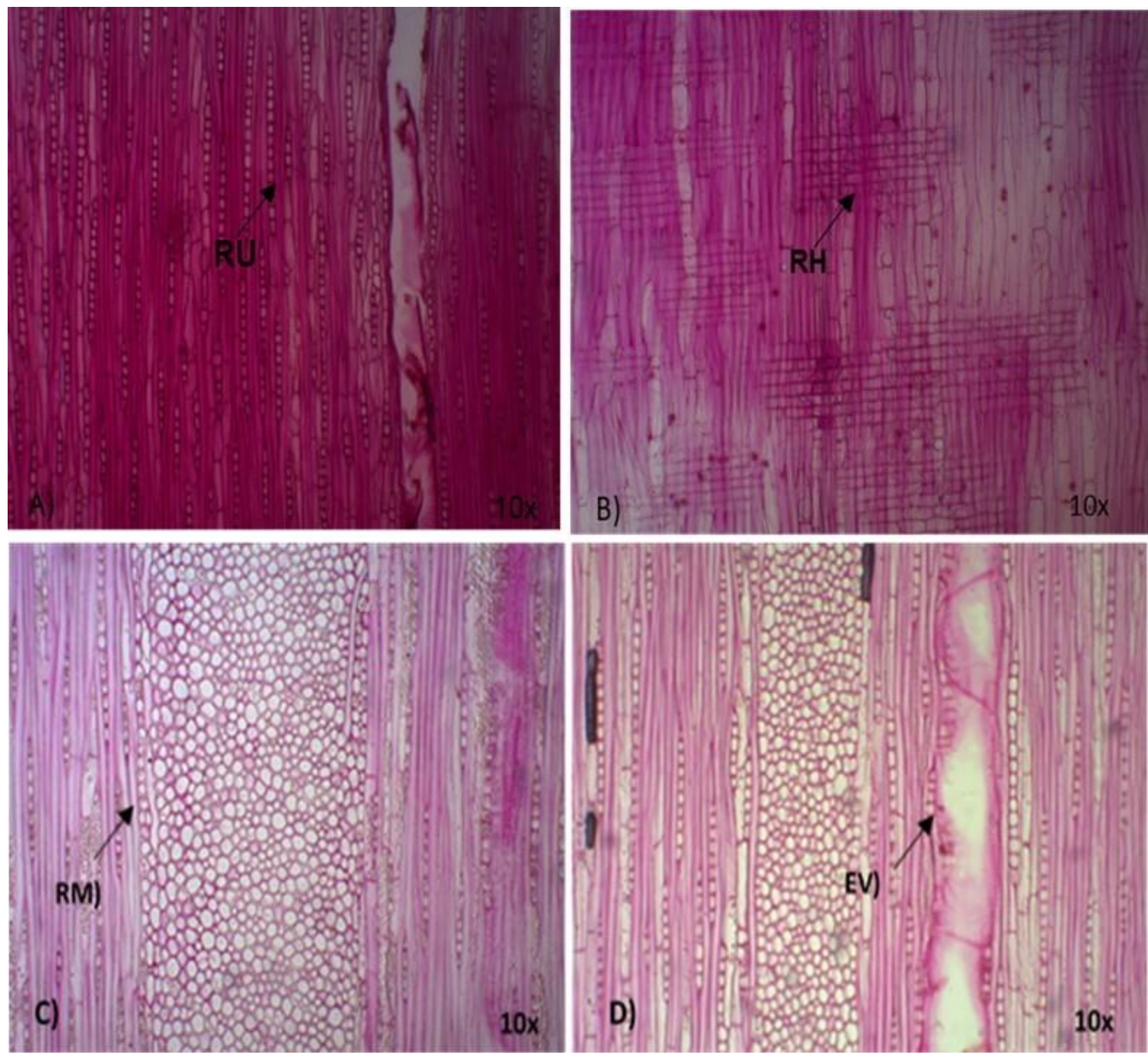

Fig. 4. Cellular elements of $Q$. macdougallii. A) tangential section $R U$ : uniseriate rays (10x); B) radial section $\mathrm{RH}$ : homogeneous rays (10x); C) tangential section $\mathrm{RM}$ : multiseriate ray (10x);

D) tangential section EV: vessel element (10x)

In the analysis of variance carried out for the uniseriate rays between sapwood and heartwood, a significant difference was found in the length $(\mathrm{p}=0.0001)$ and in the number of rays per $\mathrm{mm}^{2}(\mathrm{p}=0.0001)$. Significant differences were found in the width $(\mathrm{p}=0.0001)$, length $(p=0.0024)$, and number of series $(p=0.0001)$. In all cases the dimensions are greater in sapwood in relation to the heartwood (Table 3), a similar behavior that was present in the wood of Quercus faginea (Sousa et al. 2014).

\section{Pulp Quality Indexes for Paper}

In both sapwood and heartwood, significant statistical differences were found in the pulp quality indices for paper at the sampling heights (Table 4), which agrees with the results shown in Tables 1, 2, and 3. The stiffness coefficient ranged from 0.42 to 0.75 (Table 4). Close values have been reported in the literature for other oak species $(Q$. scytophylla $0.47, Q$. resinosa 0.78) (Vázquez-Gaviña et al. 2010). In relation to the flexibility coefficient, values ranging from 0.25 to 0.58 (Table 4) were like those found in other oak species (Q. resinosa $0.22, Q$. scytophylla 0.53 ) (Vázquez-Gaviña et al. 2010). 
Table 3. Dimensions and Number of Wood Ray Cells of $Q$. macdougallii by Height

\begin{tabular}{|c|c|c|c|c|c|c|}
\hline \multicolumn{7}{|c|}{ Uniseriate Rays } \\
\hline \multirow{2}{*}{ Dimensions } & \multirow{2}{*}{ Type } & \multicolumn{4}{|c|}{ Height $(\mathrm{m})$} & \multirow{2}{*}{ Mean } \\
\hline & & 0.30 & 1.30 & 3.00 & 6.00 & \\
\hline \multirow{2}{*}{ Width $(\mu \mathrm{m})$} & Sapwood & $\begin{array}{c}14.84 \\
(4.01) a b, A\end{array}$ & $\begin{array}{c}15.84 \\
(4.39) \mathrm{b} \\
\mathrm{A}\end{array}$ & $\begin{array}{c}14.82(3.65) \\
a b, A\end{array}$ & $\begin{array}{c}12.97 \\
(3.89) \mathrm{a}, \mathrm{A}\end{array}$ & $\begin{array}{c}14.62(3.99) \\
A\end{array}$ \\
\hline & Heartwood & $\begin{array}{c}14.76 \\
(3.99) \mathrm{b}, \mathrm{A}\end{array}$ & $\begin{array}{c}15.01 \\
(4.59) \mathrm{b} \\
\mathrm{A}\end{array}$ & $\begin{array}{c}15.43 \\
(4.67) \mathrm{b}, \mathrm{A}\end{array}$ & $\begin{array}{c}11.97 \\
(4.01) \mathrm{a}, \mathrm{A}\end{array}$ & $\begin{array}{c}14.29(4.41) \\
A\end{array}$ \\
\hline \multirow{2}{*}{$\begin{array}{l}\text { Length } \\
(\mu \mathrm{m})\end{array}$} & Sapwood & $\begin{array}{c}334.65 \\
(103.39) \mathrm{a}, \\
\mathrm{B}\end{array}$ & $\begin{array}{c}355.19 \\
(116.69) \\
a, B\end{array}$ & $\begin{array}{c}322.69 \\
(106.43) \mathrm{a}, \\
\mathrm{B}\end{array}$ & $\begin{array}{c}275.01 \\
(95.19) \mathrm{a} \\
\text { A }\end{array}$ & $\begin{array}{c}321.88 \\
(104.35) \mathrm{B}\end{array}$ \\
\hline & Heartwood & $\begin{array}{c}230.54 \\
(69.93) a, A\end{array}$ & $\begin{array}{c}250.49 \\
\text { a, A }\end{array}$ & $\begin{array}{c}252.58 \\
(121.75) \mathrm{a} \\
\mathrm{A}\end{array}$ & $\begin{array}{c}252.56 \\
(115.51) \mathrm{a} \\
\mathrm{A}\end{array}$ & $\begin{array}{c}246.54 \\
(97.14) A\end{array}$ \\
\hline \multirow[t]{2}{*}{ No. cells } & Sapwood & $\begin{array}{c}10(5.09) \mathrm{a} \\
\mathrm{A}\end{array}$ & $\begin{array}{c}13 \\
(5.79) \mathrm{a} \\
\mathrm{A}\end{array}$ & $\begin{array}{c}13(5.28) a \\
A\end{array}$ & $\begin{array}{c}13 \\
(5.19) \mathrm{a}, \mathrm{A}\end{array}$ & $\begin{array}{c}12.16(5.42) \\
A\end{array}$ \\
\hline & Heartwood & $\begin{array}{c}12(3.89) \mathrm{a} \\
\mathrm{A}\end{array}$ & $12 \mathrm{a}, \mathrm{A}$ & $\begin{array}{c}13(5.84) a \\
A\end{array}$ & $\begin{array}{c}13 \\
(5.50) \mathrm{a}, \mathrm{A}\end{array}$ & $\begin{array}{c}12.37(5.03) \\
\mathrm{A}\end{array}$ \\
\hline \multirow{2}{*}{ No. $\left(\mathrm{mm}^{-2}\right)$} & Sapwood & $26(5.02) b$ & $\begin{array}{c}20(3.64) \\
a\end{array}$ & $27(4.86) \mathrm{b}$ & $32(4.63) c$ & $\begin{array}{c}26.24(4.48) \\
A\end{array}$ \\
\hline & Heartwood & $27(6.28) a$ & $35 b$ & $43(8.59) c$ & $38(7.24) b$ & $\begin{array}{c}35.92(6.86) \\
B\end{array}$ \\
\hline \multicolumn{7}{|c|}{ Multiseriate Rays } \\
\hline \multirow{2}{*}{ Width $(\mu \mathrm{m})$} & Sapwood & $\begin{array}{c}376.55 \\
(115.68) \mathrm{c} \\
\mathrm{B}\end{array}$ & $\begin{array}{c}279.88 \\
(74.29) a, \\
B\end{array}$ & $\begin{array}{c}334.22 \\
(68.13) \mathrm{bc}, \mathrm{B}\end{array}$ & $\begin{array}{c}324.53 \\
(71.76) \mathrm{b} \\
\mathrm{B}\end{array}$ & $\begin{array}{c}328.79 \\
(81.63) \mathrm{B}\end{array}$ \\
\hline & Heartwood & $\begin{array}{c}257.19 \\
(86.73) \mathrm{a}, \mathrm{A}\end{array}$ & $\begin{array}{c}256.21 \\
(71.85) a \\
A\end{array}$ & $\begin{array}{c}272.53 \\
(62.94) \mathrm{a}, \mathrm{A}\end{array}$ & $\begin{array}{c}247.35 \\
(74.87) \mathrm{a} \\
\mathrm{A}\end{array}$ & $\begin{array}{c}258.39 \\
(74.57) \mathrm{A}\end{array}$ \\
\hline \multirow{2}{*}{$\begin{array}{l}\text { Length } \\
(\mathrm{cm})\end{array}$} & Sapwood & $\begin{array}{c}2.97 \\
(1.24) \mathrm{C}, \mathrm{B}\end{array}$ & $\begin{array}{c}2.87 \\
(0.86) \mathrm{bc}, \\
\mathrm{B}\end{array}$ & $\begin{array}{c}2.06 \\
(0.77) \mathrm{a}, \mathrm{A}\end{array}$ & $\begin{array}{c}2.24 \\
(0.94) \mathrm{ab} \\
\mathrm{A}\end{array}$ & $2.54(1.03) \mathrm{B}$ \\
\hline & Heartwood & $\begin{array}{c}2.42 \\
(0.84) \mathrm{a}, \mathrm{A}\end{array}$ & $\begin{array}{c}2.11 \\
(0.68) a \\
A\end{array}$ & $\begin{array}{c}2.20 \\
(0.78) \mathrm{a}, \mathrm{A}\end{array}$ & $\begin{array}{c}2.25 \\
(0.84) \mathrm{a}, \mathrm{A}\end{array}$ & $2.25(0.78) A$ \\
\hline \multirow{2}{*}{$\begin{array}{l}\text { No. of } \\
\text { series }\end{array}$} & Sapwood & $\begin{array}{c}18(5.83) b \\
B\end{array}$ & $\begin{array}{c}15 \\
(3.29) a \\
B\end{array}$ & $\begin{array}{c}15(2.86) \mathrm{a} \\
\mathrm{B}\end{array}$ & $\begin{array}{c}16 \\
(3.81) a b \\
B\end{array}$ & $\begin{array}{c}15.95(4.21) \\
B\end{array}$ \\
\hline & Heartwood & $\begin{array}{c}12(3.08) a \\
A\end{array}$ & $\begin{array}{r}13 \mathrm{ab}, \\
(3.31) \mathrm{A}\end{array}$ & $\begin{array}{c}14(3.67) b \\
A\end{array}$ & $\begin{array}{c}14 \\
(3.54)) b \\
A\end{array}$ & $\begin{array}{c}13.46(3.51) \\
A\end{array}$ \\
\hline
\end{tabular}

For the case of the slenderness index, the results obtained ranged from 76.68 to 109.43 (Table 4), close to values reported for other oak woods ( $Q$. laeta 78.89, Q. resinosa 90.36) (Vázquez-Gaviña et al. 2010). Finally, for the Runkel index, data ranged from 0.74 to 3.21 (Table 4) and in general were consistent with previous reports for other oak woods (Q. scytophylla 0.88, Q. glaucoides 3.35) (Vázquez-Gaviña et al. 2010). 
The average value of the stiffness coefficient for the fibers of the wood of $Q$. macdougallii is 0.55 , which is close to Quercus castanea at 0.58 . The thickness of the cell wall is classified as thick. The average value of the coefficient of flexibility is 0.47 , close to $Q$. obtusata (0.45) (Vázquez-Gaviña et al. 2010). These values correspond to the classification of thick-walled fibers, which means that the fibers generate little contact surface and therefore have little bonding between them. This also means the fibers have little mechanical resistance in the paper (Villaseñor and Rutiaga 2000). These results agree with the classification of the density of sapwood (moderately heavy) and heartwood (heavy) of $Q$. macdougallii. This is because dense woods have fibers with thick to very thick cell walls (Ninin 1985).

The average value of Runkel's index for $Q$. macdougallii wood is 1.44 , thus the fibers of this wood are classified as regular for paper (Villaseñor and Rutiaga 2000). Other Mexican woods of the same genus have obtained the same classification $(Q$. obtusata, $Q$. castanea, $Q$. candicans, $Q$. laurina, $Q$. crassipes, $Q$. laeta, and $Q$. deserticola) (VázquezGaviña et al. 2010).

Table 4. Pulp Quality Indexes for Q. macdougallii by Height

\begin{tabular}{|c|c|c|c|c|c|c|}
\hline \multirow{2}{*}{ Indexes } & \multirow{2}{*}{ Type } & \multicolumn{4}{|c|}{ Height $(\mathrm{m})$} & \multirow{2}{*}{ Mean } \\
\hline & & 0.30 & 1.30 & 3.00 & 6.00 & \\
\hline \multirow{2}{*}{ CR } & Sapwood & $\begin{array}{c}0.46 \\
(0.08) \mathrm{bc}, \mathrm{A}\end{array}$ & $\begin{array}{c}0.53 \\
(0.10) \mathrm{a}, \mathrm{A} \\
\end{array}$ & $\begin{array}{c}0.42 \\
(0.10) \mathrm{C}, \mathrm{A}\end{array}$ & $\begin{array}{c}0.47 \\
(0.15) a b, A \\
\end{array}$ & $0.47(0.12) \mathrm{A}$ \\
\hline & Heartwood & $\begin{array}{c}0.75 \\
(0.07) \mathrm{a}, \mathrm{B} \\
\end{array}$ & $\begin{array}{c}0.62 \\
(0.12) \mathrm{b}, \mathrm{B} \\
\end{array}$ & $\begin{array}{c}0.58 \\
(0.12) \mathrm{C}, \mathrm{B} \\
\end{array}$ & $\begin{array}{c}0.53 \\
(0.13) \mathrm{d}, \mathrm{B}\end{array}$ & $0.62(0.15) \mathrm{B}$ \\
\hline \multirow{2}{*}{ CF } & Sapwood & $\begin{array}{c}0.54 \\
(0.08) \mathrm{ab}, \mathrm{B}\end{array}$ & $\begin{array}{c}0.47 \\
(0.10) \mathrm{C}, \mathrm{B}\end{array}$ & $\begin{array}{c}0.58 \\
(0.10) \mathrm{a}, \mathrm{A}\end{array}$ & $\begin{array}{c}0.53 \\
(0.15) \mathrm{bc}, \mathrm{A}\end{array}$ & $0.53(0.12) \mathrm{B}$ \\
\hline & Heartwood & $\begin{array}{c}0.25 \\
(0.07) \mathrm{d}, \mathrm{A}\end{array}$ & $\begin{array}{c}0.38 \\
(0.12) \mathrm{c}, \mathrm{A}\end{array}$ & $\begin{array}{c}0.53 \\
(0.12) a, \mathrm{~B}\end{array}$ & $\begin{array}{c}0.47 \\
(0.13) \mathrm{b}, \mathrm{A}\end{array}$ & $0.41(0.15) \mathrm{A}$ \\
\hline \multirow{2}{*}{ IE } & Sapwood & $\begin{array}{c}80.92 \\
(21.13) b, A\end{array}$ & $\begin{array}{c}87.51 \\
(17.87) a b, A\end{array}$ & $\begin{array}{c}81.44 \\
(20.60) \mathrm{b} \\
\mathrm{A}\end{array}$ & $\begin{array}{c}96.02 \\
(30.72) \mathrm{a}, \mathrm{A}\end{array}$ & $\begin{array}{c}86.47(23.47) \\
\text { A }\end{array}$ \\
\hline & Heartwood & $\begin{array}{c}95.43 \\
(21.10) \mathrm{a}, \mathrm{B}\end{array}$ & $\begin{array}{c}109.43 \\
(23.82) \mathrm{a}, \mathrm{B}\end{array}$ & $\begin{array}{c}76.58 \\
(27.47) a \\
A\end{array}$ & $\begin{array}{c}100.17 \\
(24.02) \mathrm{a}, \mathrm{A}\end{array}$ & $\begin{array}{c}95.40(26.78) \\
\text { B }\end{array}$ \\
\hline \multirow{2}{*}{$\mathrm{RR}$} & Sapwood & $\begin{array}{c}0.88 \\
(0.29) \mathrm{ab}, \mathrm{A}\end{array}$ & $\begin{array}{c}1.22 \\
(0.59) \mathrm{a}, \mathrm{A}\end{array}$ & $\begin{array}{c}0.74 \\
(0.31) \mathrm{b}, \mathrm{A}\end{array}$ & $\begin{array}{c}1.16 \\
(0.60) \mathrm{a}, \mathrm{A}\end{array}$ & $1.00(0.70) \mathrm{A}$ \\
\hline & Heartwood & $\begin{array}{c}3.21 \\
(1.10) \mathrm{A} \\
\end{array}$ & $1.97(1.13) \mathrm{B}$ & $\begin{array}{c}0.98 \\
(0.51) \mathrm{C}\end{array}$ & $\begin{array}{c}1.30 \\
(0.72) \mathrm{C} \\
\end{array}$ & $1.87(1.24) \mathrm{B}$ \\
\hline \multicolumn{7}{|c|}{$\begin{array}{l}\text { Note: } C R \text { - stiffness coefficient; CF - flexibility coefficient; IE - slenderness index; RR - Runkel's } \\
\text { ratio. Equal lowercase letters in the direction of the rows indicate statistical equality }(p<0.05) \text { and } \\
\text { equal uppercase letters in the direction of the columns indicate statistical equality by the type of } \\
\text { wood }(p<0.05) \text {. The values in parenthesis represent the standard deviation. }\end{array}$} \\
\hline
\end{tabular}

\section{Physical Properties}

\section{Moisture content}

The moisture content of $Q$. macdougallii wood did not show significant differences between the different heights. However, by type of wood the moisture content in the sapwood was significantly higher in relation to the heartwood ( $\mathrm{p}=0.0007)$. Sapwood contains the cells responsible for the conduction of water, whereas the heartwood pores are obstructed by tyloses that block the conduction of water. This causes a reduction in the permeability of the wood, so the moisture content is low. The behavior presented in the 
wood of Quercus suber L. is the opposite to this convention (Leal et al. 2012).

\section{Density}

The basic density obtained for $Q$. macdougallii according to the mean is classified for sapwood as moderately heavy (Torelli 1982). This is like the reports for the wood of Quercus sartorii Liebm, Q. mexicana (Honorato 2002), and Q. dealbata (Sharma et al. 2011). Heartwood is classified as heavy (Torelli 1982), similar to that reported for Quercus semiserrata (Sharma et al. 2011), Q. sideroxyla (De la Paz Pérez et al. 2015), Q. Mexicana, Q. uxoris Mc Vaugh (De la Paz-Pérez and Dávalos-Sotelo 2008), and Q. affinis Scheid. (Bárcenas and Dávalos 1999).

In the densities analyzed, it was observed that they decrease when the height in the stem increases (Table 5). Knapic et al. (2011) and Leal et al. (2012) found similar behavior in Quercus faginea and Q. suber L., respectively. The anhydrous density of sapwood wood according to the mean is like the reports for $Q$. sartorii and $Q$. mexicana wood (Honorato 2002). However, it is lower compared to the reports for $Q$. obtusata (Honorato and Fuentes 2001).

Table 5. Wood Density of $Q$. macdougallii by Height

\begin{tabular}{|c|c|c|c|c|c|c|}
\hline \multirow{2}{*}{ Density $\left(\mathrm{g} \mathrm{cm}^{-3}\right)$} & \multirow{2}{*}{ Type } & \multicolumn{4}{|c|}{ Height $(m)$} & \multirow{2}{*}{ Mean } \\
\hline & & 0.30 & 1.30 & 3.00 & 6.00 & \\
\hline \multirow{2}{*}{ Green } & Sapwood & $\begin{array}{c}1.10 \\
(0.04) b \\
A\end{array}$ & $\begin{array}{c}1.03 \\
(0.01) \mathrm{a} \mathrm{A}\end{array}$ & $\begin{array}{c}1.01 \\
(0.04) \mathrm{a}, \mathrm{A}\end{array}$ & $\begin{array}{c}1.03 \\
(0.01) \mathrm{a} A\end{array}$ & $\begin{array}{c}1.04 \\
(0.05) \mathrm{A}\end{array}$ \\
\hline & $\begin{array}{l}\text { Heart- } \\
\text { wood }\end{array}$ & $\begin{array}{c}1.15 \\
(0.01) a \\
B\end{array}$ & $\begin{array}{c}1.33 \\
(0.34) a \mathrm{~B}\end{array}$ & $\begin{array}{c}1.07 \\
(0.01) \mathrm{a}, \mathrm{B}\end{array}$ & $\begin{array}{c}1.04 \\
(0.01) \mathrm{a} A\end{array}$ & $\begin{array}{c}1.15 \\
(0.22) \mathrm{B}\end{array}$ \\
\hline \multirow{2}{*}{ Normal } & Sapwood & $\begin{array}{c}0.79 \\
(0.08) \mathrm{b} \\
\mathrm{A}\end{array}$ & $\begin{array}{c}0.78 \\
(0.13) \mathrm{b}, \mathrm{A}\end{array}$ & $\begin{array}{c}0.71 \\
(0.03) a b, A\end{array}$ & $\begin{array}{c}0.67 \\
(0.01) \mathrm{a}, \mathrm{A}\end{array}$ & $\begin{array}{c}0.73 \\
(0.10) \mathrm{A}\end{array}$ \\
\hline & $\begin{array}{l}\text { Heart- } \\
\text { wood }\end{array}$ & $\begin{array}{c}1.25 \\
(0.16) c \\
B\end{array}$ & $\begin{array}{c}1.06 \\
(0.09) \mathrm{bc}, \mathrm{B}\end{array}$ & $\begin{array}{c}0.79 \\
(0.02) a b, A\end{array}$ & $\begin{array}{c}0.81 \\
(0.07) \mathrm{a}, \mathrm{B}\end{array}$ & $\begin{array}{c}0.98 \\
(0.22) \mathrm{B}\end{array}$ \\
\hline \multirow{2}{*}{ Anhydrous } & Sapwood & $\begin{array}{c}0.73 \\
(0.05) b \\
A\end{array}$ & $\begin{array}{c}0.70 \\
(0.04) a b, A\end{array}$ & $\begin{array}{c}0.66 \\
(0.04) \mathrm{a} A\end{array}$ & $\begin{array}{c}0.66 \\
(0.01) \mathrm{a} A\end{array}$ & $\begin{array}{c}0.69 \\
(0.05) \mathrm{A}\end{array}$ \\
\hline & $\begin{array}{l}\text { Heart- } \\
\text { wood }\end{array}$ & $\begin{array}{c}0.85 \\
(0.02) \mathrm{c} \\
\mathrm{B}\end{array}$ & $\begin{array}{c}0.79 \\
(0.06) \mathrm{bc}, \mathrm{B}\end{array}$ & $\begin{array}{c}0.71 \\
(0.02) a b, B\end{array}$ & $\begin{array}{c}0.69 \\
(0.01) \mathrm{a}, \mathrm{A}\end{array}$ & $\begin{array}{c}0.76 \\
(0.08) \mathrm{B}\end{array}$ \\
\hline \multirow{2}{*}{ Basic } & Sapwood & $\begin{array}{c}0.58 \\
(0.03) b \\
A\end{array}$ & $\begin{array}{c}0.57 \\
(0.03) a b, A\end{array}$ & $\begin{array}{c}0.54 \\
(0.03) \mathrm{a}, \mathrm{A}\end{array}$ & $\begin{array}{c}0.54 \\
(0.01) \mathrm{a}, \mathrm{A}\end{array}$ & $\begin{array}{c}0.55 \\
(0.03) A\end{array}$ \\
\hline & $\begin{array}{l}\text { Heart- } \\
\text { wood }\end{array}$ & $\begin{array}{c}0.64 \\
(0.01) \mathrm{b} \\
\mathrm{B}\end{array}$ & $\begin{array}{c}0.64 \\
(0.05) \mathrm{b}, \mathrm{B}\end{array}$ & $\begin{array}{c}0.58 \\
(0.01) a b, B\end{array}$ & $\begin{array}{c}0.56 \\
(0.01) \mathrm{a}, \mathrm{A}\end{array}$ & $\begin{array}{c}0.61 \\
(0.05) \mathrm{B}\end{array}$ \\
\hline
\end{tabular}

${ }^{*}$ Note: Equal lowercase letters in the direction of the rows indicate statistical equality $(p<0.05)$ and equal uppercase letters in the direction of the columns indicate statistical equality by the type of wood $(p<0.05)$. The values in parenthesis represent the standard deviation.

The density of wood depends on the amount and type of cellular elements that constitute it (Navarro-Martinez et al. 2005). Most of the physical and mechanical properties of wood such as hardness, weight, impact resistance, and shrinkage rates are directly related to density (Rodríguez et al. 2015). 
Woods with high densities have fibers with thick to very thick walls (Ninin 1985) and present a greater resistance to cutting and difficulty of workability (Navarro-Martinez et al. 2005; Leon 2010). They have a high natural durability and have fewer empty spaces that minimize the access of water. The thickness of the walls gives it weight and the hardness necessary for use in construction (Interián-ku et al. 2011).

Between the type of wood (sapwood and heartwood), significant differences were found in green density $(\mathrm{p}=0.0010)$, normal density $(\mathrm{p}=0.0001)$, anhydrous density $(\mathrm{p}=$ $0.0001)$, and basic density ( $\mathrm{p}=0.0001)$. In all cases, the density of the heartwood is greater than that of the sapwood. Heartwood has a greater density of fibers than of vessels, has fibers with thicker walls (Panshin and Dezeew 1980), and the heartwood has a greater amount of extractives compared to the sapwood. These are the reasons why there is a difference in density between both tissues (Kellogg 1981).

In studies conducted for species of the genus Quercus, it was found that the basic density of the wood of Q. faginea (Knapic et al. 2011) and Q. suber (Knapic et al. 2008) decreased radially from the pith to the bark. This is a behavior similar to the results reported in this study.

\section{Fiber saturation point}

The fiber saturation point (FSP) for sapwood (33.73) and heartwood (29.12) showed significant differences $(\mathrm{p}=0.0001)$. This variation is due to heartwood having a higher presence of extracts that occupy places inside the cell wall, thus limiting the attraction between water molecules. Wood with a high content of extracts has a relatively low fiber saturation point (Panshin and Dezeeuw 1980). The FSP according to the average is classified as high (Sallenave 1955), in which similar values have been reported for Quercus robur wood (Kolin and Janezic 1996), Q. convallata Trel. (Honorato 2002), and Q. suber L. (Leal et al. 2012).

\section{Shrinkage and anisotropy relationship}

Tangential, radial, and volumetric shrinkage (Table 6) in relation to the mean, is classified as very high in sapwood and heartwood (Echenique et al. 1975). Tangential and radial shrinkage obtained in the wood of $Q$. macdougallii are within the range reported for the European oak species. Shrinkage varies between 4.0 to $6.6 \%$ and 8.6 to $13.0 \%$ in the radial and the tangential direction, respectively (Tsoumis 1991). High values in shrinkage indicate a lower dimensional stability of the wood, which requires more care in the wood drying process. There will be a greater tendency to the presence of jointing and fissures in the material (Ruiz-Aquino et al. 2018).

Table 6. Shrinkage and Anisotropy Relationship of Q. macdougallii

\begin{tabular}{|c|c|c|c|c|c|}
\hline \multirow{2}{*}{ Type } & \multicolumn{4}{|c|}{ Shrinkage } & AR \\
\hline & Tangential & Radial & Longitudinal & Volumetric & \\
\hline Sapwood & $12.73(2.22) \mathrm{A}$ & $\begin{array}{c}5.15(0.86) \\
A\end{array}$ & $0.20(0.17) \mathrm{A}$ & $19.34(2.58) \mathrm{A}$ & $2.52(0.52) A$ \\
\hline Heartwood & 11.76 (1.15) A & $\begin{array}{c}6.31(0.94) \\
B\end{array}$ & $0.24(0.17) \mathrm{A}$ & $19.63(1.84) \mathrm{A}$ & $1.90(0.38) \mathrm{B}$ \\
\hline
\end{tabular}

Ruiz-Aquino et al. (2020). "Quercus macdougallii," BioResources 15(3), 5975-5998. 
In the radial direction, the rays favor contractions restricting the dimensional movements (Boyd 1974). The radial walls of the wood cells have a lignin content greater than the content in the tangential walls. This explains the smaller values of shrinkage in the radial direction. Since the lignin is more rigid and less hygroscopic than the holocellulose, it limits the contraction (Bosshard 1956).

The anisotropy ratio (AR) is classified according to the mean for sapwood as very high and for heartwood as high (Echenique et al. 1975). AR expresses the relationship between the tangential and radial behavior. The larger and greater magnitude of the problem depends on the presence of uniseriate and multiseriate rays (Igartúa et al. 2009).

\section{Chemical Analysis}

The result of the chemical analysis is summarized in Table 7. The $\mathrm{pH}$ values ranged from 4.41 to 4.83 and had a weak acidic $\mathrm{pH}$ (Kollmann 1959). Heartwood was found to be more acidic than sapwood, which is consistent with the literature (Fengel and Wegener 1984; Rutiaga 2001). The $\mathrm{pH}$ values found here are slightly lower than those reported for wood from different oak species (4.6 to 5.9) (Rutiaga 2001), (4.74 to 5.10) (Herrera et al. 2017).

The content of mineral substances varied from 4.41 to $4.83 \%$ and these results generally coincide with previous reports for woods of the same genus (Rutiaga et al. 2000; Bautista and Honorato 2005; Herrera et al. 2017). The extractives can be extracted from wood or bark with polar and nonpolar solvents (Hillis 1987). In our study material most of the extractives correspond to polar substances, and this fact has also been recently observed in Quercus faginea (Miranda et al. 2017; Ferreira et al. 2018). Finally, heartwood has a higher proportion of solvent-extractable compounds than sapwood, and these values generally coincide with data for oak woods (Fengel and Wegener 1984; Rutiaga 2001; Bautista and Honorato 2005; Herrera et al. 2017).

In relation to cell wall chemicals, Runkel lignin values were $14.86 \%$ for heartwood and $16.79 \%$ for sapwood. These values are within the range reported for some oak woods (14.67 to 19.37\%) (Herrera et al. 2017). In the case of holocellulose, the value obtained for both heartwood $(73.58 \%)$ and sapwood $(73.16 \%)$ is practically the same but is lower than that reported for other woods of the same genus (81.63 to 90.72\%) (Herrera et al. 2017). However, this result generally coincides with the range reported for hardwoods (Fengel and Wegener 1984).

The low ash content, the low total solubility compared to the applied extraction sequence, and the low lignin content suggest that the wood of this oak species could be used in the chemical pulping process to obtain cellulose pulp for making paper.

Table 7. Summary of the Chemical Analysis of Q. macdougallii Wood

\begin{tabular}{|c|c|c|}
\hline Analysis & Heartwood & Sapwood \\
\hline $\mathrm{pH}$ & $4.41(0.05)$ & $4.83(0.03)$ \\
\hline Ash (\%) & $0.59(0.01)$ & $0.49(0.01)$ \\
\hline Cyclohexane (\%) & $0.80(0.24)$ & $0.11(0.80)$ \\
\hline Acetone (\%) & $4.47(0.22)$ & $3.18(0.96)$ \\
\hline Methanol (\%) & $2.39(0.07)$ & $2.50(0.37)$ \\
\hline Hot water (\%) & $1.68(0.20)$ & $7.24(0.00)$ \\
\hline Total extractives (\%) & $8.35(0.10)$ & $16.79(0.22)$ \\
\hline Runkel lignin (\%) & $14.86(0.10)$ & $73.16(0.58)$ \\
\hline Holocellulose (\%) & $73.58(0.75)$ & \\
\hline The values in parenthesis represent the standard deviation. \\
\hline
\end{tabular}

Ruiz-Aquino et al. (2020). "Quercus macdougallii," BioResources 15(3), 5975-5998. 
Table 8 shows the result of the microanalysis of wood ashes from Q. macdougallii. Nine chemical elements were identified in the heartwood and eight in the sapwood. Aluminium was not detected in the latter. The chemical elements present in $Q$. macdougallii are practically the same as those reported in woods of the same genus identified by the same method (Rutiaga 2001; Herrera et al. 2017) with variations in concentration. The results obtained here reveal the typical presence of the chemical elements that are common in wood (potassium, calcium, and magnesium) (Fengel and Wegener 1984). In this oak wood, the presence of heavy elements was not detected.

Table 8. Microanalysis of Q. macdougallii ash (at\%)

\begin{tabular}{|c|c|c|}
\hline Element & Heartwood & Sapwood \\
\hline Sodium & $4.32(0.28)$ & $1.37(0.31)$ \\
\hline Magnesium & $7.83(0.66)$ & $7.21(0.04)$ \\
\hline Aluminum & $0.19(0.11)$ & $*$ \\
\hline Silicon & $0.64(0.12)$ & $0.42(0.01)$ \\
\hline Phosphorus & $1.13(0.09)$ & $4.69(0.05)$ \\
\hline Sulfur & $6.28(0.63)$ & $1.64(0.21)$ \\
\hline Potassium & $49.48(1.14)$ & $57.46(0.57)$ \\
\hline Calcium & $26.33(0.09)$ & $24.40(0.67)$ \\
\hline Manganese & $3.29(0.18)$ & $3.12(0.09)$ \\
\hline
\end{tabular}

\section{CONCLUSIONS}

1. The sapwood of Quercus macdougallii Martínez presented a very pale-yellow color in contrast to the reddish yellow of the heartwood, straight grain, low gloss, pronounced veining, and thick texture.

2. The fiber length increases from the base to the crown in sapwood.

3. The fiber diameter was classified as fine, the fiber wall thickness as medium, and the length as medium.

4. The width and length of the multiseriate rays are greater in sapwood than in heartwood, which are characteristics that influence the drying process negatively.

5. Basic density in sapwood $\left(0.55 \mathrm{~g} \mathrm{~cm}^{-3}\right)$ and in heartwood $\left(0.61 \mathrm{~g} \mathrm{~cm}^{-3}\right)$ is classified as moderately heavy and heavy, respectively.

6. The saturation point of the fiber is classified as high.

7. The basic density indicates better physical properties in the heartwood and the anisotropy ratio suggests high dimensional changes in the tangential direction, so radial cuts should be favored in the sawing process.

8. The fibers are classified as regular for paper manufacture and based on its chemical composition this wood could be used in the production of cellulose pulp for paper manufacturing. 


\section{ACKNOWLEDGMENTS}

The authors wish to thank the Comisariado de Bienes Comunales of the Municipality of Santiago Comaltepec, for the facilities provided for the development of the research Grant No. CAUP 2-EA-1804.

This work is dedicated to the memory of Juana Huerta Crespo (Universidad Autónoma Chapingo, México).

\section{REFERENCES CITED}

Aguilar, R. S., and Castro, B. P. (2006). “Anatomía de la madera de doce especies del bosque mesófilo de montaña del Estado de México [Wood anatomy of twelve species of the mesophilic mountain forest of the State of Mexico]," Madera y Bosques 12(1), 95-115. DOI: $10.21829 /$ myb.2006.1211252

Anacleto-Carmona, E. (2015). Abundancia y distribución de Quercus macdougallii (Fagaceae), especie endémica de la Sierra Juárez. Tesis de Licenciatura [Abundance and distribution of Quercus macdougallii (Fagaceae), an endemic species of the Sierra Juárez. Bachelor Thesis], Universidad de la Sierra Juárez, Ixtlán de Juárez, Oaxaca, México.

Antúnez, P., Quiñones-Pérez, Z., Santiago-García, W., and Suárez-Mota, M. E. (2018). "Funciones de densidad: Una aplicación para delimitar intervalos óptimos de clima y fisiografía para especies forestales [Density functions: An application for delimiting optimal intervals of climate and physiography for forest species]," Agrociencia 52(7), 1031-1042. http://www.scielo.org.mx/pdf/agro/v52n7/2521-9766-agro-52-07-1031en.pdf

ASTM D 143-94 (2007). "Standard test methods for small clear specimens of timber," ASTM International, West Conshohocken, Pennsylvania.

Ávila, S. C. G. (1985). "Secado en estufa de la madera aserrada de mezclas de encinos rojos y blancos [Kiln-drying of sawn wood of mixed red and white oaks]," in: Memoria del II seminario nacional sobre utilización de encinos, Guadalajara, Jalisco, pp. 218-228.

Bakhshi, R., Kiaei, M., and Mosavi, S. M. S. (2012). "Wood properties variation along radial position in Quercus castaneaefolia," Middle-East Journal of Scientific Research, 11(4), 511-516. https://www.idosi.org/mejsr/mejsr11(4)12/16.pdf

Bárcenas, P. G. M., Ortega, E. F., Álvarez, A. G., and Ronzón, P. P. (2005). “Relación estructura-propiedades de la madera de angiospermas mexicanas [Structure-properties relationship of Mexican angiosperm wood]," Universidad y Ciencia 21(42), 45-55. DOI: https://www.redalyc.org/articulo.oa?id=15404201

Bárcenas, P. G. M., Terrazas, S. T., Dávalos, S. R., and Honorato, S. J. A. (2002). "Efecto del contenido de lignina, extractivos, radios y densidad relativa o básica en las contracciones de cinco especies de madera [Effect of lignin content, extracts, rays, and relative or basic density on shrinkage of five wood species]," in: Memorias del IV Congreso Mexicano de Tecnología de Productos Forestales, Guadalajara, Jalisco, México, pp. 33-34.

Bárcenas, P. G., and Dávalos, S. R. (1999). “Importancia de la lignina en las contracciones de la madera: revisión bibliográfica [Importance of lignin in wood shrinkage: bibliographic review]," Madera y Bosques 5(1), 13-26. DOI: 
10.21829/myb.1999.511351

Bautista, H. R., and Honorato, S. J. A. (2005). "Composición química de la madera de cuatro especies del género Quercus [Chemical composition of the wood of four species of the genus Quercus]," Revista Ciencia Forestal en México 30(98), 25-49.

Bosshard, H. H. (1956). "Über die Anisotropie der Holzschwindung [About the Anisotropy of Wood Shrinkage]," Holz Roh Werkst. 14(8), 285-295. DOI: 10.1007/BF02605214

Boyd, J. D. (1974). "Anisotropic shrinkage of wood: Identification of the dominant determinants," Mokuzai Gakkaishi 20(10), 473-482. https://pascalfrancis.inist.fr/vibad/index.php?action=getRecordDetail\&idt=PASCAL7588007711

Chattaway, M. (1932). "Proposed standards for numerical values used in describing woods," Tropical Wood 29, 20-28.

Chávez, R. D. M., Aguilar, R. S., and Terrazas, T. (2010). "Variación anatómica en la madera de Quercus obtusata (Fagaceae) [Anatomical variation in Quercus obtusata (Fagaceae) wood]," Madera y Bosques 16(2), 69-87. DOI:

10.21829/myb.2010.1621173

Clark-Tapia, R., Ochoa, M. A., Aguirre, H. V., Antúnez, P., Contreras, E. C. J., Valencia, S., and Alfonso, C. C. (2018). "Reproducción sexual de Quercus macdougallii, un encino endémico de la Sierra Juárez, Oaxaca [Sexual reproducion of Quercus macdougallii, an endemic oak of Sierra Juárez, Oaxaca]," Madera y Bosques 24(2), e2421617. DOI: 10.21829/myb.2018.2421617

Clark-Tapia, T. R., Suárez, M. M. E., Nolasco, M. M., and Velasco, F. H. (2016). "Clima: pasado, presente y future [Climate: past, present and future]," in: Recursos hídricos de la Sierra Norte de Oaxaca: caracterización, diagnóstico y gestion, ClarkTapia, R., Ramos-Morales, M. F., Alfonso-Corrado, C., Mendoza-Díaz, M. M., and Fuente-Carrasco, M. (ed.), Universidad de la Sierra Juárez, México, pp. 38-47.

Dadswell, H. E., Watson, A. J., and Nicholls, J. W. (1959). "What are the wood properties required by the paper industry in the trees of the future?," Tappi 42(7), 521-526.

De la Paz Pérez, O. C., and Dávalos-Sotelo, R. (2008). "Algunas características anatómicas y tecnológicas de la madera de 24 especies de Quercus (encinos) de México [Some anatomical and technological characteristics of 24 Quercus wood species (oaks) of Mexico]," Madera y Bosques 14(3), 43-80. DOI: 10.21829/myb.2008.1431206

De la Paz Pérez, O. C. (2000). Relación estructura propiedades físico-mecánicas de la madera de algunas especies de encinos (Quercus) Mexicanas [Structure relationship physico-mechanical properties of the wood of some Mexican oak (Quercus) species], Doctoral Thesis, Facultad de Ciencias, Universidad Nacional Autónoma de México, México.

De la Paz Pérez, O. C., and Quintanar, I. A. (1994). “Características anatómicas de la madera de cinco especies del estado de Jalisco, México [Anatomical characteristics of the wood of five species from the state of Jalisco, Mexico]," Acta Botánica Mexicana 27, 75-87. DOI: 10.21829/abm27.1994.711

De la Paz Pérez, O. C., Campos, R. A., Quintanar, I. A., and Dávalos-Sotelo, R. (1998). "Estudio anatómico de la madera de cinco especies del genero Quercus (Fagaceae) del estado de Veracruz [Anatomical study of the wood of five species of the genus Quercus (Fagaceae) from the state of Veracruz]," Madera y Bosques 4(2), 45-65. DOI: $10.21829 /$ myb.1998.421359 
De la Paz Pérez, O. C., Dávalos-Sotelo, R., Quintanar, I. A, and Paz, A. (2005). "Influencia de los radios en algunas propiedades físicas y mecánicas de la madera de ocho encinos (Quercus) de Durango, México [Influence of the rays on some physical and mechanical properties of the wood of eight oaks (Quercus) from Durango, Mexico]," Madera y Bosques 11(2), 49-68. DOI: 10.21829/myb.2005.1121256

De la Paz Pérez, O. C., Dávalos-Sotelo, R., Limón, G. R., and Quintanar, I. A. (2015). "Características tecnológicas de la madera de dos especies de Quercus de Durango, México [Technological characteristics of the wood of two Quercus species from Durango, Mexico]," Madera y Bosques (21)3, 19-46. DOI:

10.21829/myb.2015.213454

De la Paz Pérez, O. C., Vélez, J. S., and Ceja, R. J. (2006). "Anatomía de la madera de ocho especies de Quercus (Fagaceae) de Oaxaca, México [Anatomy of the wood of eight species of Quercus (Fagaceae) from Oaxaca, Mexico]," Madera y Bosques 12(1), 63-94. DOI: 10.21829/myb.2006.1211251

De la Paz Pérez, O. C., and Corral, L. G. (1980). "Estudio anatómico de la madera de once especies de angiospermas [Anatomical study of the wood of eleven species of angiosperms]," Instituto Nacional de Investigaciones Forestales, México.

Dinwoodie, J. M. (1965). "The relationship between fiber morphology and paper properties: A review of literature," Tappi 48(8), 440-447.

Echenique, M. R., Barajas, J., Pinzón, L., and Pérez, M. V. (1975). Estudio botánico y ecológico de la región del río Uxpanapa, Ver. 1. Características tecnológicas de la madera de 10 especies, INIREB, México, pp. 66.

Fengel, D., and Wegener, G. (1984). Wood Chemistry, Ultrastructure, Reactions, Walter de Gruyter \& Co., Berlin, Germany.

Ferreira, J. P. A., Miranda, I., Sousa, V. B., and Pereira, H. (2018). “Chemical composition of barks from Quercus faginea trees and characterization of their lipophilic and polar extracts," PLoS ONE 13(5), e0197135. DOI:

10.1371/journal.pone.0197135

Fuentes-Salinas, M. (2000). "Estimación del punto de saturación de la fibra (PSF) de las maderas [Estimation of the fiber saturation point (PSF) of woods]," Revista Chapingo Series Forestales y del Ambiente 6(1), 79-81.

García, E. L., Guindeo, A., Peraza, O. C., and de Palacios, P. P. (2003). La madera y su anatomía: anomalías y defectos, estructura microscópica de coníferas y frondosas, identificación de maderas, descripción de especies y pared celular [Wood and its anatomy: anomalies and defects, microscopic structure of conifers and hardwoods, wood identification, species and cell wall description], Fundación Conde del Valle de Salazar, Mundi Prensa, Madrid.

González, R. H., Maiti, R., Kumari, A., and Sarkar, N. (2016). "Variability in wood density and wood fibre characterization of woody species and their possible utility in Northeastern Mexico," American Journal of Plant Sciences 7, 1139-1150. DOI: 10.4236/ajps.2016.77109

Herrera-Fernández, A. C., Carrillo-Parra, A., Pedraza-Bucio, F. E., Correa-Méndez, F., Herrera-Bucio, R., López-Albarrán, P., and Rutiaga-Quiñones, J. G. (2017). "Densidad, composición química y poder calorífico de la madera de tres especies de encino (Quercus candicans, Q. laurina y Q. rugosa) [Density, chemical composition and calorific value of the wood of three oak species (Quercus candicans, Q. laurina and Q. rugosa)]," Ciencia Nicolaita 72, 136-154. 
Hillis, W.E. (1987). Heartwood and Tree Exudates, Springer-Verlag, Berlin Heidelberg, Germany.

Honorato, S. J. A. (2002). “Características anatómicas de la madera de encinos [Anatomical characteristics of oak wood]," in: Características, propiedades y procesos de transformación de la madera de los encinos de México, Quintanar O. J. (ed.), INIFAP-CIRCE, C.E., San Martinito, Tlahuapan, Puebla, México, pp. 34-65.

Honorato, S. J. A., and Fuentes, L. M. E. (2001). "Propiedades Físico-Mecánicas de la madera de cinco especies del estado de Guanajuato [Physical-mechanical properties of the wood of five species from the state of Guanajuato]," Revista Ciencia Forestal en México 26(90), 5-28.

IAWA Committee (1937). "Standard terms of length of vessel members and wood fibers," Tropical Woods 51, 21-22.

IAWA Committee (1939). "Standard terms of size for vessel diameter and ray width," Tropical Woods 59, 51-52.

IAWA Committee (1989). "List of microscopic features for hardwood identification," IAWA Bulletin 10(3), 219-332.

Igartúa, D. V., Monteoliva, S., and Piter, J. C. (2009). "Estudio de algunas propiedades físicas de la madera de Acacia malanoxylon en Argentina [Study of some physical properties of Acacia malanoxylon wood in Argentina]," Maderas. Ciencia y Tecnología 11(1), 3-18. DOI: 10.4067/S0718-221X2009000100001

INEGI (2016). Anuario estadístico y geográfico de Oaxaca, Instituto Nacional de Estadística, Geografía, México.

Interián-Ku, V. M., Borja de la Rosa, M. A., Valdez-Hernández, J. I., García-Moya, E., Romero-Manzanares, A., and Vaquera-Huerta, H. (2011). "Características anatómicas y propiedades físicas de la madera de Caesalpinia gaumeri Greenm en Dzan, Yucatán [Anatomical characteristics and physycal properties of wood of Caesalpinia gaumeri Greenm in Dzan, Yucatan]," Madera y Bosques 17(1), 23-36. DOI: 10.21829/myb.2011.1711152

Kellogg, R. (1981). "Physical properties of wood," in: Wood: Its Structure and Properties, Wangaard, F. (ed.), Forest Products Laboratory, Forest Service, USDA, Wisconsin, pp. 187-224.

Kiaei, M., and Samariha, A. (2011). "Fiber dimensions, physical and mechanical properties of five important hardwood plants," Indian Journal of Science and Technology 4(11), 1460-1464. DOI: 10.17485/ijst/2011/v4i11/30270

Knapic, S., Louzaba, J. L., and Pereira, H. (2011). "Variation in wood density components within and between Quercus faginea trees," Canadian Journal of Forest Research 41(5), 1212-1219. DOI: 10.1139/x11-038

Knapic, S., Louzada, J., Leal, S., and Pereira, H. (2008). "Within-tree and between-tree variation of wood density components in cork oak trees in two sites in Portugal," Forestry 81(4), 465-473. DOI: 10.1093/forestry/cpn012

Kolin, B., and Janezic, S. (1996). "The effect of temperature, density, and chemical composition upon the limit of hygroscopicity of wood," Holzforschung 50, 263-268. DOI: $10.1515 / \mathrm{hfsg} .1996 .50 .3 .263$

Kollmann, F. (1959). Tecnología de la madera y sus aplicaciones (Tomo I) [Wood technology and its applications], Inst. For. de Invest. y Exp. y el Serv. de la Mad, Madrid, España.

Kremer, A., Abbott, A. G., Carlson, J. E., Manos, P. S., Plomion, C., Sisco, P., Staton, M. E., Ueno, S., and Vendramin, G. G. (2012). "Genomics of Fagaceae," Tree Genetics 
\& Genomes 8(3), 583-610. DOI: 10.1007/s11295-012-0498-3

Leal, S., Sousa, V., and Pereira, H. (2012). "Cork oak (Quercus suber L.) wood hygroscopic properties and dimensional stability," Forest Systems 21(3), 355-363. DOI: $10.5424 / \mathrm{fs} / 2012213-02104$

Leal, S., Sousa, V., Knapic, S., Louzada, J., and Pereira, H. (2011). "Vessel size and number are contributors to define wood density in cork oak," European Journal of Forest Research 130, 1023-1029. DOI: 10.1007/s10342-011-0487-3

Lei, H., Milota, R. M., and Gartner, L. B. (1996). "Between and within-tree variation in the anatomy and specific gravity of wood in Oregon white oak (Quecus garryana Dougl.)," IAWA Journal 17(4), 445-461. DOI: 10.1163/22941932-90000642

León, H. W. H. (2010). "Anatomía y densidad o peso específico de la madera [Anatomy and density or specific weight of the wood]," Revista Forestal Venezolana 54(1), 6776.

León, H. W. J., and Espinoza, P. N. (2001). “Anatomía de la madera,” in: Consejo de Desarrollo Científico, Humanístico y Tecnológico, Mérida 1a. (ed), Consejo de publicaciones de la Universidad de los Andes, Venezuela, pp. 511.

Mejía-Díaz, L. A., and Rutiaga-Quiñones, J. G. (2008). "Chemical composition of Schinus molle L. wood and kraft pulping process," Revista Mexicana de Ingeniería Química 7(2), 145-149.

Metcalfe, C. R., and Chalk, L. (1985). Anatomy of the Dicotyledons: Wood Structure and Conclusion of the General Introduction, Clarendon Press, Oxford.

Miranda, I., Sousa, V., Ferreira, J., and Pereira, H. (2017). "Chemical characterization and extractives composition of heartwood and sapwood from Quercus faginea," PLoS ONE 12(6), e0179268. DOI: 10.1371/journal.pone.0179268

Moglia, J. G., Giménez, A. M., and Bravo, S. (2014). Tomo II Macroscopía de la madera, Facultad de Ciencias Forestales, Universidad Nacional de Santiago del Estero, Argentina.

Munsell Color Company (1975). Munsell Soil Color Charts, Baltimore, MD, USA.

Navarro-Martínez, J., Borja-de la Rosa, A., and Machuca, V. R. (2005). "Características tecnológicas de la madera de Palo Morado (Peltogyne mexicana Martínez) de Tierra Colorada, Guerrero, México [Technological characteristics of the wood of purpleheart (Peltogyne mexicana Martínez) from Tierra Colorada, Guerrero, Mexico]," Revista Chapingo. Serie Ciencias Forestales y del Ambiente 11(1), 73-82.

Ninin, L. (1985). Manual de aserrado y afilado [Sawing and sharpening manual], Universidad de Los Andes, Facultad de Ciencias Forestales, Departamento de Publicaciones, Mérida, Venezuela.

Palacios, J. H., Lomelí, R. M. G., and Zamora, N. J. F. (2013). "La estructura interna de la madera: Herramienta para manejo y aprovechamiento de los recursos forestales," in: Recursos Forestales en el Occidente de México: Biodiversidad, manejo, producción, aprovechamiento y conservación, Salcedo-Pérez, E, Hernández- Álvarez, E, Vázquez-García, J. A. Díaz-Echavarría, N. (ed.), Amaya Ediciones, México, pp. 643.

Panshin, A. J., and Dezeeuw, C. (1980). Textbook of Wood Technology, Editorial McGraw-Hill, New York, U. S. A.

Pariona, N., Martínez, A. I., Hernández-Flores, H., and Clark-Tapia, R. (2017). "Effect of magnetite nanoparticles on the germination and early growth of Quercus macdougallii," Science of the Total Environment 575, 869-875. DOI: 10.1016/j.scitotenv.2016.09.128

Petroff, G., and Normand, D. (1965). "The correlation between the physical and 
mechanical properties of paper, and dimensional characteristics of paper, from tropical hardwoods," Pulp and paper development in Africa and the Near East. FAO meeting, Cairo 1965, pp. 269-287.

Phelps, J. E., and Workman, E. C. (1994). "Vessel area studies in White oak (Quercus alba L.)," Wood and Fiber Science 26(3), 315-322.

Pineda, H. E., De la Paz Pérez, O C., Dávalos, S. R., and Valdez, H. (2012).

"Características tecnológicas de la madera de dos especies de Costa Grande, Guerrero, México [Technological characteristics of two wood species from Costa Grande, Guerrero, México]," Madera y Bosques 18(3), 53-71. DOI: 10.21829/myb.2012.183358

Porres, C., and Valladares, J. (1979). "Producción de pulpa y papel con materias primas autóctonas centroamericanas [Pulp and paper production with indigenous Central American raw materials], ” Instituto Centroamericano de Investigación y Tecnología Industrial, Guatemala, $72 \mathrm{pp}$.

Quintanar, I. A., Jacobo, V. M. A., López, B. C., Flores, H. N., Jaramillo, P. A. T., and De la Paz Pérez, O. C. (2012). "La madera de Trema micrantha (L.) Blume de Veracruz, México [Wood of Trema micrantha (L.) Blume from Veracruz, México]," Madera y Bosques 18(2), 73-91. DOI: 10.21829/myb.2012.182353

Ramos, C., and Díaz, V. (1981). Instrucciones para Colectar Muestras de Madera para Estudios Tecnológicos [Instructions for collecting wood samples for technological studies], Instituto Nacional de Investigaciones Forestales, México.

Robson, J. (2008). Plan de Manejo de la Biodiversidad [Biodiversity Management Plan], Comunidad Santiago Comaltepec, Distrito de Ixtlán de Juárez, Oaxaca.

Rodríguez, A. R., Ramírez, A. A. M., Palacios, J. H., Fuentes, T. F. J., Silva, G. J. A., and Saucedo, C. A. R. (2015). "Características anatómicas, físico-mecánicas y de maquinado de la madera de mezquite (Prosopis velutina Wooton) [Anatomical, physical-mechanical and machining characteristics of the wood of velvet mesquite (Prosopis velutina Wooton)]," Revista Mexicana de Ciencias Forestales 6(28), 156173. DOI: $10.29298 /$ rmcf.v6i28.257

Rodríguez, A., Palacios, J. H. R., and Lomelí, R. M. G. (2007). “Estructura anatómica de la madera [Anatomical structure of wood]," Revista Ciencia y Desarrollo 33(213), 24-29. http://www.cyd.conacyt.gob.mx/archivo/213/Articulos/Madera/Madera00.html

Ruiz-Aquino, F., González-Peña, M. M., Valdez-Hernández, J. I., and RomeroManzanares, A. (2016). "Estructura anatómica de dos encinos de Oaxaca [Anatomical structure of the wood of two oaks from Oaxaca]," Madera y Bosques 22(1), 177-189. DOI: $10.21829 /$ myb.2016.221485

Ruiz-Aquino, F., González-Peña, M. M., Valdez-Hernández, J. I., Romero-Manzanares, A., and Fuentes-Salinas, M. (2018). "Mechanical properties of wood of two Mexican oaks: relationship to selected physical properties," European Journal of Wood and Wood Products 76, 69-77. DOI: 10.1007/s00107-017-1168-9

Runkel, R., and Wilke, Y. K. D. (1951). "Zur Kenntnis des thermoplastischen Verhaltens von Holz," Holz als Roh- und Werkstoff 9(7), 260-270. DOI: 10.1007/BF02617370

Rutiaga-Quiñones, J. G. (2001). Chemische und biologische Untersuchungen zum Verhalten dauerhafter Holzarten und ihrer Extrakte gegenüber holzabbauenden Pilzen [Chemical and biological investigations on the behavior of durable wood species and their extracts towards wood degrading fungi], Buchverlag Gräfelfing, Germany. 
Rutiaga-Quiñones, J. G., Windeisen, E., and Strobel, C. (2000). “Composición química del duramen de la madera de Quercus candicans Neé [Chemical composition of the heartwood of Quercus candicans Neé wood]," Madera y Bosques 6(2), 73-80. DOI: 10.21829/myb.2000.621375

Sallenave, P. (1955). Propriétés Physiques et Méchaniques des Bois Tropicaux de l'Union Française, Centro Technique Forestier Tropical, Nagent, Sur-Marme.

Sandermann, W., and Rothkamm, M. (1959). "Über die Bedeutung der pH-Werte von Handelsholzern und deren Bedeutung für die Praxis," Holz als Roh- und Werstoff 17(11), 433-440. DOI: 10.1007/BF02605386

SAS Institute (2002). User Guide: SAS/STAT (Version 9.0), SAS Institute, Cary, NC.

Savilla, P. S. (1986). "Anatomical characters in the wood of oak (Quercus robur L. and Quercus petraea Liebl.) which predispose trees to shake," Commonwealth Forest Revue 65, 109-116.

Sharma, M., Sharma, C. L., Kharkongor, B. and Carter, M. (2011). "Wood anatomical variations in some species of Quercus of Meghalaya," J. Indian Acad. Wood Sci. 8(2), 152-157. DOI: 10.1007/s13196-012-0057-4

Sousa, V. B., Cardoso, S., and Pereira, H. (2014). "Age trends in the wood anatomy of Quercus faginea," IAWA Journal 35(3), 293-306. DOI 10.1163/22941932-00000067

TAPPI T 211 om-93 (2000). "Ash in wood and pulp," TAPPI Press, Atlanta, GA.

Téllez-Sánchez, C., Ochoa-Ruiz, H. G., Sanjuán-Dueñas, R., and Rutiaga-Quiñones, J. G. (2010). "Componentes químicos del duramen de Andira inermis (W. Wright) DC. (Leguminosae) [Chemical components of heartwood in Andira inermis (w. wright) DC. (Leguminosae)]," Revista Chapingo Serie Ciencias Forestales y del Ambiente 16(1), 87-93. DOI: 10.5154/r.rchscfa.2099.11.046

Torelli, L. (1982). Estudio Promocional de 43 Especies Forestales Tropicales Mexicanas [Promotional study of 43 Mexican tropical forest species], SARH-INIF, México.

Tortorelli, L. (1956). "Maderas y bosques Argentinos," Administración Nacional de Bosques, Editorial ACME, Buenos Aires, Argentina.

Tsoumis, G. (1991). Science and Technology of Wood, Van Nostrand Reinhold, New York, USA.

Valencia, A. S., and Barajas, M. J. (1995). "Comparación de la anatomía de Quercus affinis y $Q$. laurina (Fagaceae) [Comparison of the anatomy of Quercus affinis and $Q$. laurina (Fagaceae)]," Anales del Instituto de Biología Serie Botánica 66(2), 113-131.

Valencia, A., and Nixon, K. C. (2004). "Encinos [Oaks]," in: Biodiversidad de Oaxaca, A. J. García-Mendoza, M. J. Ordóñez, M. Briones-Salas (eds), Instituto de Biología, Universidad Nacional Autónoma de México (UNAM), Fondo Oaxaqueño para la Conservación de la Naturaleza and WWF, México DF, pp. 219-225.

Vázquez-Gaviña, Y., Guridi-Gómez, L. I., Rutiaga-Quiñones, J. G. (2010). "Posibilidades de uso de 98 maderas para el proceso de pulpeo kraft, con base a sus índices de calidad de pulpa [Possibilities of using 98 woods for the kraft pulping process, based on their pulp quality indexes]," Revista Ciencia Nicolaita 52, 87-102.

Villaseñor-Araiza, J. C., and Rutiaga-Quiñones, J. G. (2000). "La madera de la Casuarina equisetifolia L., química e índices de calidad de pulpa [The wood of Casuarina equisetifolia L., chemistry and pulp quality indexes]," Madera y Bosques 6(1), 29-40. DOI: 10.21829/myb.2000.611340

Wilson, K., and White, D. J. B. (1986). The Anatomy Wood: Its Diversity and Variability, Stobart and Son LTD, London, Great Britain. 
Wise, L.E., Murphy, M., and D'Addieco, A. A. (1946). "Chlorite holocellulose, its fraction and bearing on summative wood analysis and on studies on hemicelluloses," Paper Trade J. 122(2), 35-43.

Zobel, B., and Talbert, J. (1994). Técnicas de mejoramiento genético de árboles forestales [Genetic improvement techniques for forest trees], LIMUSA, México, D. F.

Article submitted: March 2, 2020; Peer-review completed: April 18, 2020; Revised version received and accepted: June 10, 2020; Published: June 17, 2020.

DOI: 10.15376/biores.15.3.5975-5998 